\title{
Structural basis of altered potency and efficacy displayed by a major in vivo metabolite of the anti-diabetic PPAR $\gamma$ drug pioglitazone
}

Sarah A. Mosure ${ }^{1,2}$, Jinsai Shang ${ }^{2}$, Richard Brust ${ }^{2}$, Jie Zheng ${ }^{3}$, Patrick R. Griffin ${ }^{2,3}$, and Douglas J. Kojetin ${ }^{2,3 *}$

From the ${ }^{1}$ Skaggs Graduate School of Chemical and Biological Sciences, Scripps Research, Jupiter, Florida 33458, USA; ${ }^{2}$ Department of Integrative Structural and Computational Biology, Scripps Research, Jupiter, Florida 33458, USA; ${ }^{3}$ Department of Molecular Medicine, Scripps Research, Jupiter, Florida 33458, USA

Running title: Structure-function analysis of 1-hydroxypioglitazone

*To whom correspondence should be addressed: author: Douglas J. Kojetin, Department of Integrative Structural and Computational Biology, The Scripps Research Institute, Jupiter, Florida 33458, USA; dkojetin@scripps.edu; Tel. (561) 228-2298; Fax. (561) 228-3088.

Keywords: ligand-binding protein, drug metabolism, X-ray crystallography, nuclear magnetic resonance (NMR), hydrogen exchange mass spectrometry (HDX-MS), peroxisome proliferatoractivated receptor gamma (PPAR $\gamma$ ), ligand-binding domain (LBD), nuclear receptor, gene transcription

\section{ABSTRACT}

The thiazolidinedione (TZD) pioglitazone (Pio) is an FDA-approved drug for type 2 diabetes mellitus that binds and activates the nuclear receptor peroxisome proliferatoractivated receptor gamma (PPAR $\gamma)$. Although TZDs have potent antidiabetic effects, they also display harmful side effects that have necessitated a better understanding of their mechanisms of action. In particular, little is known about the effect of in vivo TZD metabolites on the structure and function of PPAR $\gamma$. Here, we present a structure-function comparison of Pio and a major in vivo metabolite, 1-hydroxypioglitazone (PioOH). $\mathrm{PioOH}$ displayed a lower binding affinity and reduced potency in coregulator recruitment assays compared to Pio. To determine the structural basis of these findings, we solved an X-ray crystal structure of $\mathrm{PioOH}$ bound to PPAR $\gamma$ ligand-binding domain (LBD) and compared it to a published Pio-bound crystal structure. PioOH exhibited an altered hydrogen bonding network that could underlie its reduced affinity and potency compared to Pio. Solution-state structural analysis using NMR spectroscopy and hydrogen/deuterium exchange mass spectrometry (HDX-MS) analysis revealed that $\mathrm{PioOH}$ stabilizes the PPAR $\gamma$ activation function-2 (AF-2) coactivator binding surface better than Pio. In support of AF-2 stabilization, PioOH displayed stabilized coactivator binding in biochemical assays and better transcriptional efficacy (maximal transactivation response) in a cellbased assay that reports on the activity of the PPAR $\gamma$ LBD. These results, which indicate that Pio hydroxylation affects both its potency and efficacy as a PPAR $\gamma$ agonist, contribute to our understanding of PPAR $\gamma$-binding drug metabolite interactions and may assist in future PPAR $\gamma$ drug design efforts.

The thiazolidinedione (TZD) pioglitazone (Pio; brand/trade name Actos) is an FDA- 
approved drug for the treatment of Type 2 Diabetes Mellitus (T2DM) (1). Pio binds and activates peroxisome proliferator-activated receptor gamma (PPAR $\gamma)$, a nuclear receptor transcription factor that regulates expression of genes important for insulin sensitivity, lipid metabolism, and inflammation (2). PPAR $\gamma$ has the conserved nuclear receptor domain architecture comprised of an N-terminal activation function-1 (AF-1) domain, a DNAbinding domain (DBD), a flexible hinge region, and C-terminal ligand-binding domain (LBD) (3). The DBD recognizes and binds PPAR response elements (PPREs) within the promoter region of target genes, and although DNA binding has been shown to affect receptor function (4-7), the PPAR $\gamma$ LBD has been the primary focus for developing therapeutics because endogenous lipids and synthetic small molecule ligands such as TZDs bind to the LBD and regulate the transcriptional activity of PPAR $\gamma$.

The PPAR $\gamma$ LBD contains $12 \alpha$-helical structural elements that form a three-layer sandwich fold; within this fold is a large hydrophobic core known as the canonical or orthosteric ligand binding pocket. Adjacent to the ligand-binding pocket, a surface formed by the three-dimensional association of helix 3 (h3), helix 4 (h4), helix 5 (h5), and helix 12 (h12) is called the activation function-2 (AF-2) coregulator interaction surface $(8,9)$. Conformational changes in the AF-2 surface that occur in response to ligand binding mediate interactions with coregulators that influence recruitment of chromatin-modifying enzymes and other transcriptional machinery to control downstream gene expression. In the absence of an activating (agonist) ligand, PPAR $\gamma$ recruits transcriptionally repressive corepressor complexes including proteins such as Nuclear Receptor Corepressor 1 (NCoR1) $(1,10)$. However, when an agonist binds to the PPAR $\gamma$ ligand-binding pocket, the AF-2 surface is stabilized, favoring loss of the corepressor complex and recruitment of coactivator proteins such as Thyroid hormone Receptor Associated Protein 220 (TRAP220) (11-13). Previous studies sought to characterize the mechanisms by which agonists activate PPAR $\gamma$, with early evidence suggesting that h12 acts as a simple "on/off” switch (14). Recent investigations support more complex mechanisms by which ligands regulate PPAR $\gamma$ function: for instance, by affecting LBD conformational dynamics $(11,15,16)$, binding to an alternate/allosteric site within the LBD $(12,17)$, or regulating post-translational modifications of PPAR $\gamma(18,19)$.

Full PPAR $\gamma$ agonists like the TZDs stabilize an active AF-2 surface conformation through a hydrogen bond network with residues near helix 12 including S289, H323, H449, and Y473 (20). Because Pio is known to have deleterious side effects such as weight gain and musculoskeletal complications, there is demand for a more sophisticated understanding of its effects on PPAR $\gamma$ structure and function (21). One area that requires further investigation is the effects of in vivo Pio metabolites. Small molecules like Pio are chemically modified by liver cytochrome P450 (CYP450) enzymes to facilitate excretion $(22,23)$. These modified metabolic intermediates can enter systemic circulation and reach serum levels as high as the original drug (24). Some TZD metabolites maintain the ability to bind and activate PPAR $\gamma$ (23), but enzymatic addition of functional groups may lead to differential regulation of PPAR $\gamma$ activity. Rezulin/troglitazone, another previously FDA-approved TZD for the treatment of T2DM, was removed from the market after a major metabolite caused hepatotoxicity (22). Therefore, it is critical to characterize the metabolites of FDA-approved drugs like Pio as well as the original small molecule.

Previous pharmacokinetic analyses of Pio (Fig. 1A) identified the major in vivo 
bioRxiv preprint doi: https://doi.org/10.1101/351346; this version posted August 13, 2018. The copyright holder for this preprint (which was not certified by peer review) is the author/funder, who has granted bioRxiv a license to display the preprint in perpetuity. It is made available under aCC-BY 4.0 International license.

\section{Structure-function analysis of 1-hydroxypioglitazone}

A

Pioglitazone (Pio)<smiles>CCc1ccc(CCOc2ccc(CC3SC(=O)NC3=O)cc2)nc1</smiles>

B

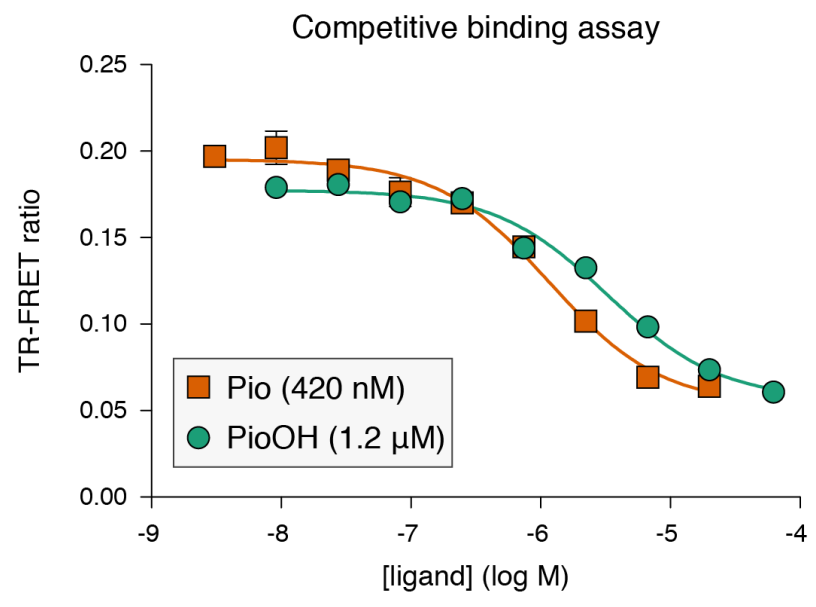

D

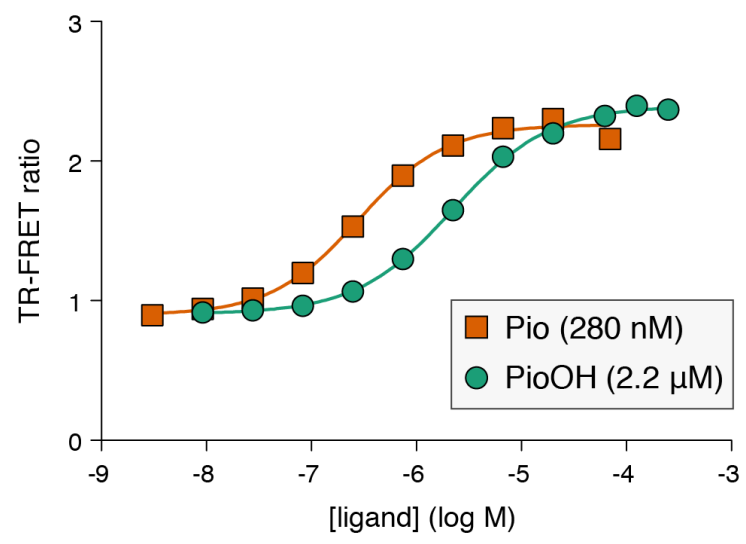

1-hydroxypioglitazone $(\mathrm{PiOOH})$<smiles>CC(O)c1ccc(CCOc2ccc(CC3SC(=O)NC3=O)cc2)nc1</smiles>

C

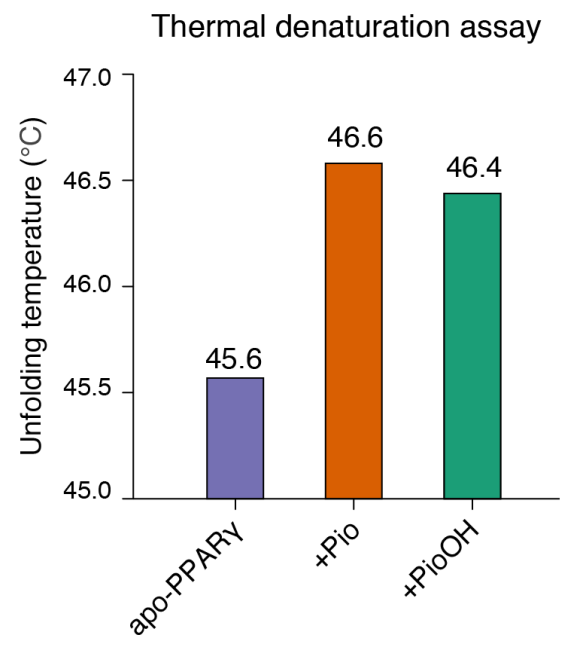

E

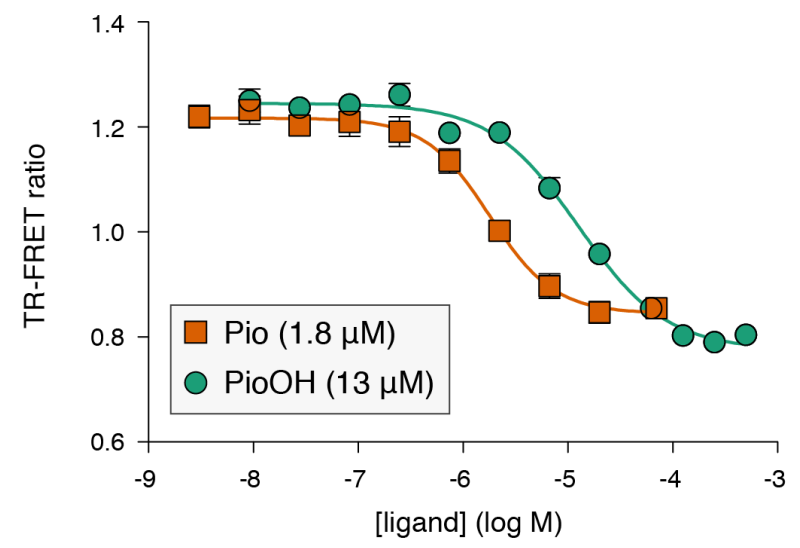

Figure 1. Functional comparison of Pio and $\mathrm{PioOH}$ in biochemical assays. (A) Chemical structures of pioglitazone (Pio; left) and the pioglitazone metabolite 1-hydroxypioglitazone (PioOH; right). (B) Competitive binding assay of His-tagged PPAR $\gamma$ LBD with titration of Pio or PioOH. Ligand $K_{i}$ values for Fluormone ${ }^{\mathrm{TM}}$ Pan-PPAR displacement are shown in the legend. (C) $\mathrm{T}_{\mathrm{m}}$ values from CD spectroscopy thermal denaturation analysis monitored at $222 \mathrm{~nm}$ of delipidated apo-PPAR $\gamma$ LBD without or with addition of one molar equivalent of ligand; $\mathrm{T}_{\mathrm{m}}$ values are noted above the bars. (D) TR-FRET assay of His-tagged PPAR $\gamma$ LBD with FITC-TRAP220 peptide with Pio or PioOH. Ligand $\mathrm{EC}_{50}$ values for peptide recruitment are shown in the legend. (E) TR-FRET of His-tagged PPAR $\gamma$ LBD with FITCNCoR1 peptide titrated with Pio or PioOH. Ligand $\mathrm{IC}_{50}$ values for peptide displacement are shown in the legend.

metabolite 1-hydroxypioglitazone (PioOH) (Fig. 1A), which exhibited weaker anti- hyperglycemic effects despite differing from Pio only by the addition of a hydroxyl group 
$(25,26)$. Human studies found that PioOH was present in human serum at equal or greater concentrations than Pio (23), emphasizing its physiological relevance. Here, we investigated how the functional effects of PioOH are related to its structural interaction with PPAR $\gamma$ LBD. Using biochemical and cellular transactivation assays, we showed that Pio hydroxylation reduces potency, as demonstrated by increased $\mathrm{EC}_{50} / \mathrm{IC}_{50}$ values in transactivation and coregulator recruitment assays, which may underlie its reduced anti-hyperglycemic effects relative to Pio in vivo. Our crystal structure of PioOH-bound PPAR $\gamma$ LBD identified changes in the ligand-receptor hydrogen bonding network that may underlie its reduced potency, while our solution-state structural analysis using protein NMR and HDX-MS revealed that PioOH stabilized the dynamics of the AF-2 surface compared to Pio. Stabilization of AF-2 surface dynamics were associated with changes in the thermodynamics of coactivator binding and enhanced efficacy in a chimeric cellular transcription assay that reports on the activity of the PPAR $\gamma$ LBD. Overall, these findings contribute to our understanding of how synthetic ligands and their in vivo metabolites fine-tune PPAR $\gamma$ function.

\section{RESULTS}

PioOH has a weaker binding affinity and coregulator recruitment potency than Pio

We first assessed the binding affinity of Pio and PioOH (Fig. 1A) to the PPAR $\gamma$ LBD using a fluorescent ligand displacement assay (Fig. 1B), which revealed that the metabolic conversion of Pio to $\mathrm{PioOH}$ via addition of a hydroxyl group to the end of the hydrophobic side-chain of Pio weakened the interaction with the PPAR $\gamma$ LBD $(\mathrm{P}<0.001)$. Circular dichroism (CD) spectroscopy thermal denaturation experiments confirmed binding and revealed that the unfolding temperature of the PPAR $\gamma$ LBD is increased upon binding both Pio and
PioOH (Fig. 1C), indicating binding of these ligands stabilized the LBD. We also performed time resolved fluorescence resonance energy transfer (TR-FRET) biochemical assays to determine how Pio and $\mathrm{PioOH}$ affect the interaction with peptides derived from a PPAR $\gamma$-interacting transcriptional coactivator (TRAP220) and corepressor (NCoR1).

Table 1. Crystallography refinement statistics.

\begin{tabular}{|c|c|}
\hline & $\begin{array}{l}\text { PPAR } \gamma \text { LBD bound to 1- } \\
\text { hydroxypioglitazone } \\
(\mathrm{PioOH})\end{array}$ \\
\hline Data collection & BCSB-5.0.2 \\
\hline Space group & C 121 \\
\hline \multicolumn{2}{|l|}{ Cell dimensions } \\
\hline$a, b, c(\AA)$ & $93.08,61.85,119.67$ \\
\hline$\alpha, \beta, \gamma\left(^{\circ}\right)$ & $90,102.73,90$ \\
\hline Resolution & $49.12-1.88(1.95-1.88)$ \\
\hline$R_{\text {pim }}$ & $0.056(0.456)$ \\
\hline $\mathrm{I} / \sigma(\mathrm{I})$ & $4.93(1.29)$ \\
\hline$C C 1 / 2$ in highest shell & 0.618 \\
\hline Completeness (\%) & $97.33(95.12)$ \\
\hline Redundancy & 1.8 \\
\hline \multicolumn{2}{|l|}{ Refinement } \\
\hline Resolution $(\AA)$ & 1.88 \\
\hline No. of reflections & 98149 \\
\hline$R_{\text {work }} / R_{\text {free }}(\%)$ & $22.05 / 25.53$ \\
\hline \multicolumn{2}{|l|}{ No. of atoms } \\
\hline Protein & 4147 \\
\hline Water & 250 \\
\hline \multicolumn{2}{|l|}{$B$-factors } \\
\hline Protein & 46.19 \\
\hline Ligand & 52.84 \\
\hline Water & 45.78 \\
\hline \multicolumn{2}{|l|}{ Root mean square deviations } \\
\hline Bond lengths $(\AA)$ & 0.008 \\
\hline Bond angles $\left({ }^{\circ}\right)$ & 0.95 \\
\hline Ramachandran favored (\%) & 96.08 \\
\hline Ramachandran outliers (\%) & 1.37 \\
\hline PDB accession code & 6DHA \\
\hline
\end{tabular}


bioRxiv preprint doi: https://doi.org/10.1101/351346; this version posted August 13, 2018. The copyright holder for this preprint (which was not certified by peer review) is the author/funder, who has granted bioRxiv a license to display the preprint in perpetuity. It is made available under aCC-BY 4.0 International license.

Structure-function analysis of 1-hydroxypioglitazone

Consistent with its reduced binding affinity, PioOH was less potent than Pio in recruiting the TRAP220 peptide (Fig. 1D) and displacing the NCoR1 peptide $(\mathrm{P}<0.001)$ (Fig. 1E).

\section{Crystal structure of PioOH-bound PPARy $L B D$ reveals an altered hydrogen bonding network}

To determine the structural basis of $\mathrm{PioOH}$ activity compared to Pio, we solved the crystal

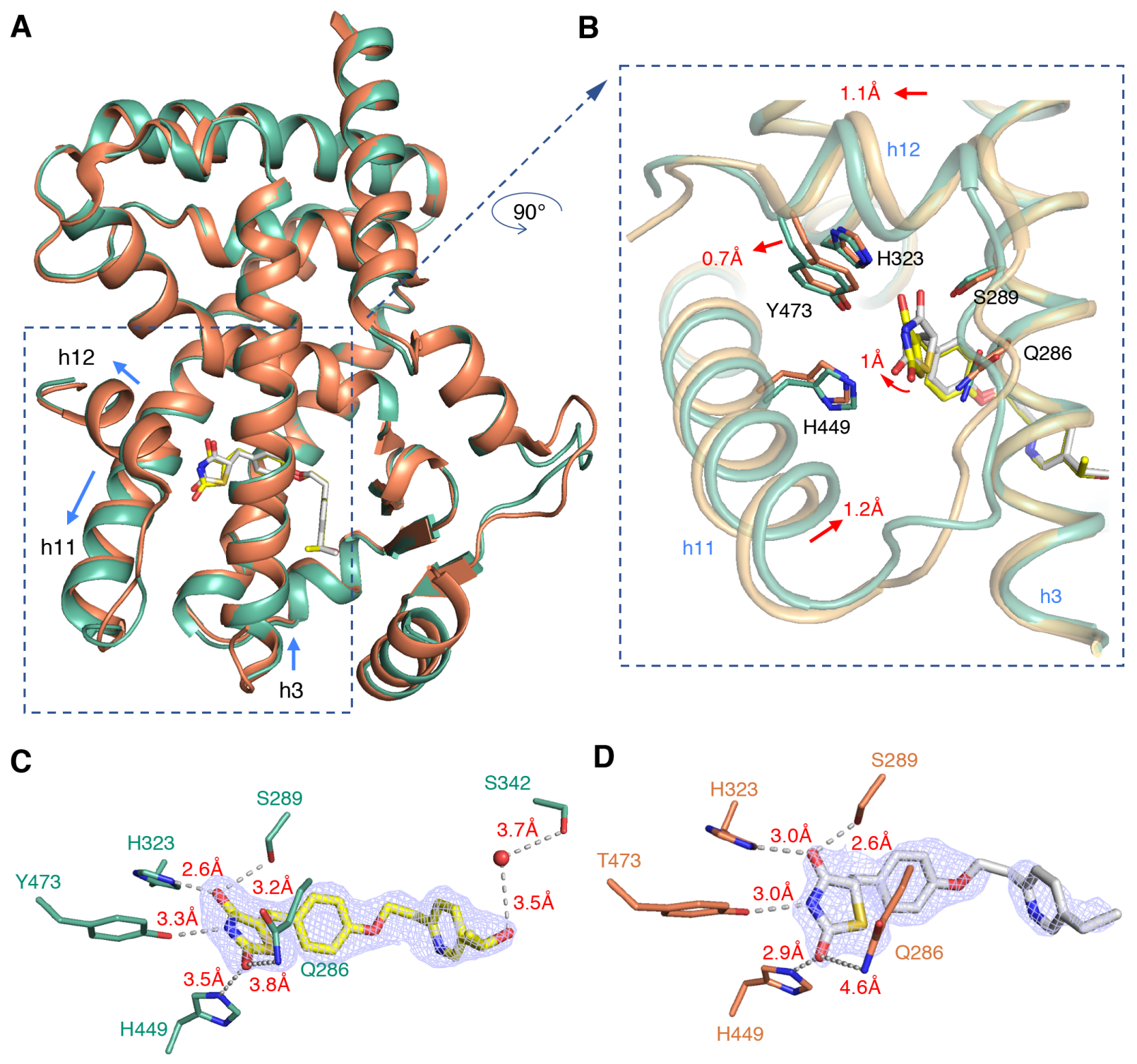

Figure 2. Comparison of PPAR $\gamma$ LBD crystal structures bound to Pio or PioOH. (A) Structural alignment of PioOHbound PPAR $\gamma$ LBD crystal structure (PDB code 6DHA, chain A; green cartoon, yellow ligand) and Pio-bound PPAR $\gamma$ LBD crystal structure (PDB code 5Y2O, chain A; orange cartoon, white ligand). (B) $90^{\circ}$ counter-clockwise rotation and zoomed in view of the region of the ligand-binding pocket that contacts the Pio and PioOH TZD head groups. The side chains of residues that form hydrogen bonds with TZD head group are shown as sticks, and red arrows indicate structural shifts in secondary structure between the Pio and PioOH-bound structures. (C,D) Omit maps ( $2 \mathrm{~F}_{\mathrm{O}}-$ $\mathrm{F}_{\mathrm{C}}$, contoured at $1 \sigma$ ) of $(\mathrm{C}) \mathrm{PioOH}$ and (D) Pio displayed with hydrogen bonds to residues within the ligand-binding pocket (gray dotted line and red text), as well as a water molecule (red sphere) in the $\mathrm{PioOH}$ structure that participates in a water-mediated hydrogen bond between the S342 side chain and the PioOH hydroxyl group (D). 
structure of PPAR $\gamma$ LBD bound to PioOH at $1.88 \AA$ resolution using molecular replacement (Table 1). The X-ray crystal structure of Pio bound to PPAR $\gamma$ LBD was recently solved at comparable resolution (1.801 $\AA$; PDB code 5Y2O) (20). Both Pio and PioOH-bound PPAR $\gamma$ LBDs crystallized as dimers: h12 in chain A adopts an "active" conformation with the ligand bound in the orthosteric pocket, whereas h12 in chain B adopts an atypical conformation in which h12 docks onto adjacent molecules within the crystal lattice. Structural alignment of chain $\mathrm{A}$ in the Pio and $\mathrm{PioOH}$ structures resulted in an overall RMSD of $0.385 \AA$ (Fig. 2A), indicating there were no overall structural changes. However, subtle structural changes (Fig. 2B) that were likely influenced by differences in the ligand-receptor hydrogen bond network (Fig. 2C,D) could explain the reduced affinity of $\mathrm{PioOH}$.

The TZD head group of both ligands form hydrogen bonds with the side chains of residues S289, H323, H449, and Y473. The hydrogen bond lengths in the PioOH-bound structure (Fig. 2C) were extended relative to the Pio-bound structure (Fig. 2D) for S289, H323, and Y473. The PioOH TZD head group was tilted $\sim 1 \AA$ such that these interacting side

chains were farther from their hydrogen bond donor/acceptor, while Q286 and H323 were closer in the PioOH-bound structure despite overall minimal changes in side chain conformations. Additionally, the $\mathrm{PioOH}$ hydroxyl group formed a weak water-mediated hydrogen bond with the side chain of S342 (Fig. 2C), which likely contributed to the change in binding mode that shifted the TZD head group of PioOH relative to Pio. The PioOH TZD head group displacement was reciprocated by a $1.1 \AA$ shift of $\mathrm{h} 12$ away from h3 and a $1.2 \AA$ shift of h11 toward h3 (Fig. 2A,B). The introduction of the hydroxyl group in PioOH shifted the binding pose of the terminal methyl group towards G284 on helix 3. However, this methyl shift did not introduce any steric clashes with residues near helix 3 . Thus, it is possible that the combination of the weakened $\mathrm{PioOH}$ hydrogen bond interactions with residues near helix 12, as well as the weak water-mediated hydrogen bond introduced by the hydroxylation of Pio, contributes to the weakened affinity and potency of $\mathrm{PioOH}$.

\section{Solution structural analysis reveals enhanced AF-2 stabilization by PioOH}

Although ligand-bound crystal structures provide important molecular detail into the binding mode of PPAR $\gamma$ ligands, it has been difficult to identify structural mechanisms of graded ligand activity, such as full vs. partial agonism, due to the structural homogeneity of protein conformations within the crystals (27). Typically, backbone conformations observed in ligand-bound PPAR $\gamma$ crystal structures are highly similar due to crystal packing forces that favor the most stable crystallized conformation, and thus they are not representative of the ensemble of conformations present in solution. Alternatively, structural studies that probe the dynamics of proteins in solution, such as NMR spectroscopy and HDX-MS, have identified more nuanced yet functionally relevant characteristics of graded activation $(11,15,16)$.

We performed differential NMR analysis by collecting 2D $\left[{ }^{1} \mathrm{H},{ }^{15} \mathrm{~N}\right]-\mathrm{TROSY}$-HSQC NMR spectra of ${ }^{15} \mathrm{~N}$-labeled PPAR $\gamma$ LBD with Pio or PioOH (Fig. 3A). NMR peaks were assigned to residues using the minimal NMR chemical shift method (28) based on their nearest neighbor to rosiglitazone-bound PPAR $\gamma$ LBD NMR chemical shift assignments (11). This method allowed us to assign 181 well-resolved peaks for PioOH and Pio; 93 residues remained unassigned mostly due to NMR peak overlap that made transfer of NMR assignments difficult (Fig. 3B). We calculated NMR chemical shift perturbations (CSPs) between the Pio- and PioOH-bound states to identify changes in the chemical environment 
bioRxiv preprint doi: https://doi.org/10.1101/351346; this version posted August 13,2018 . The copyright holder for this preprint (which was not certified by peer review) is the author/funder, who has granted bioRxiv a license to display the preprint in perpetuity. It is made available under aCC-BY 4.0 International license.

\section{Structure-function analysis of 1-hydroxypioglitazone}

A

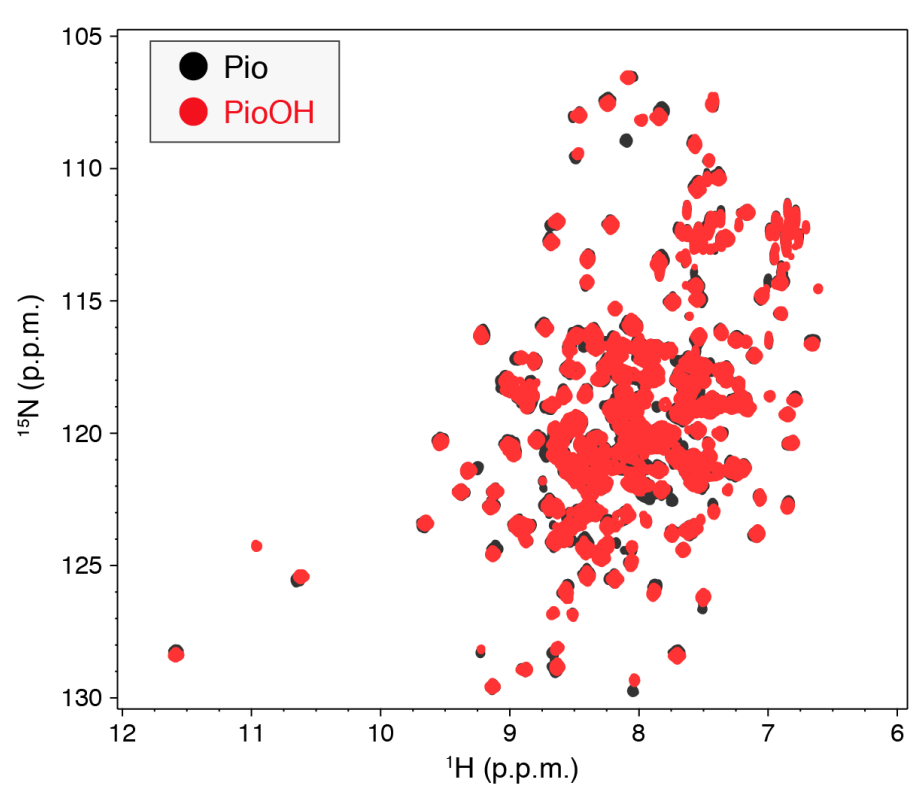

B

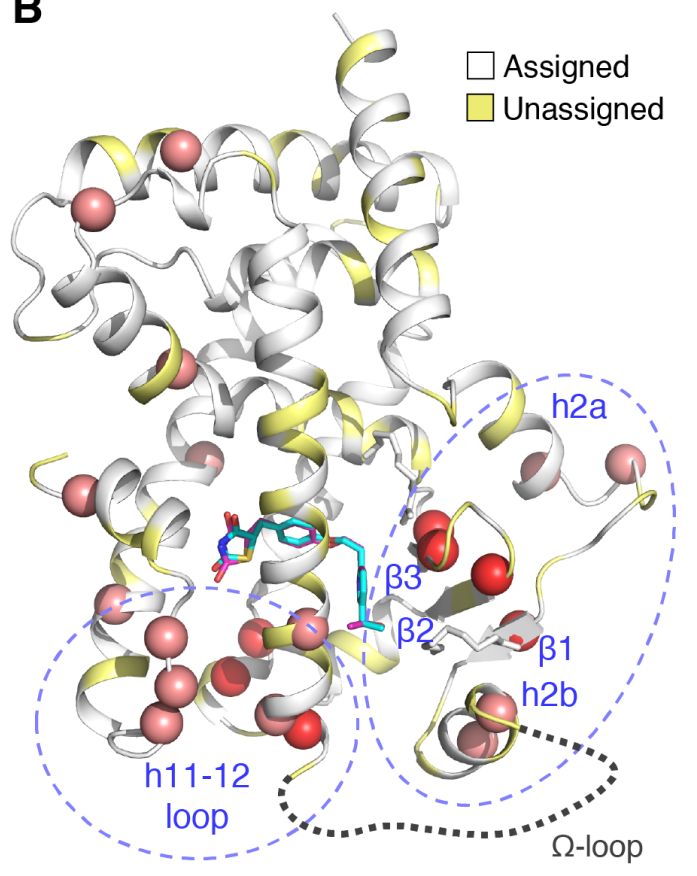

C

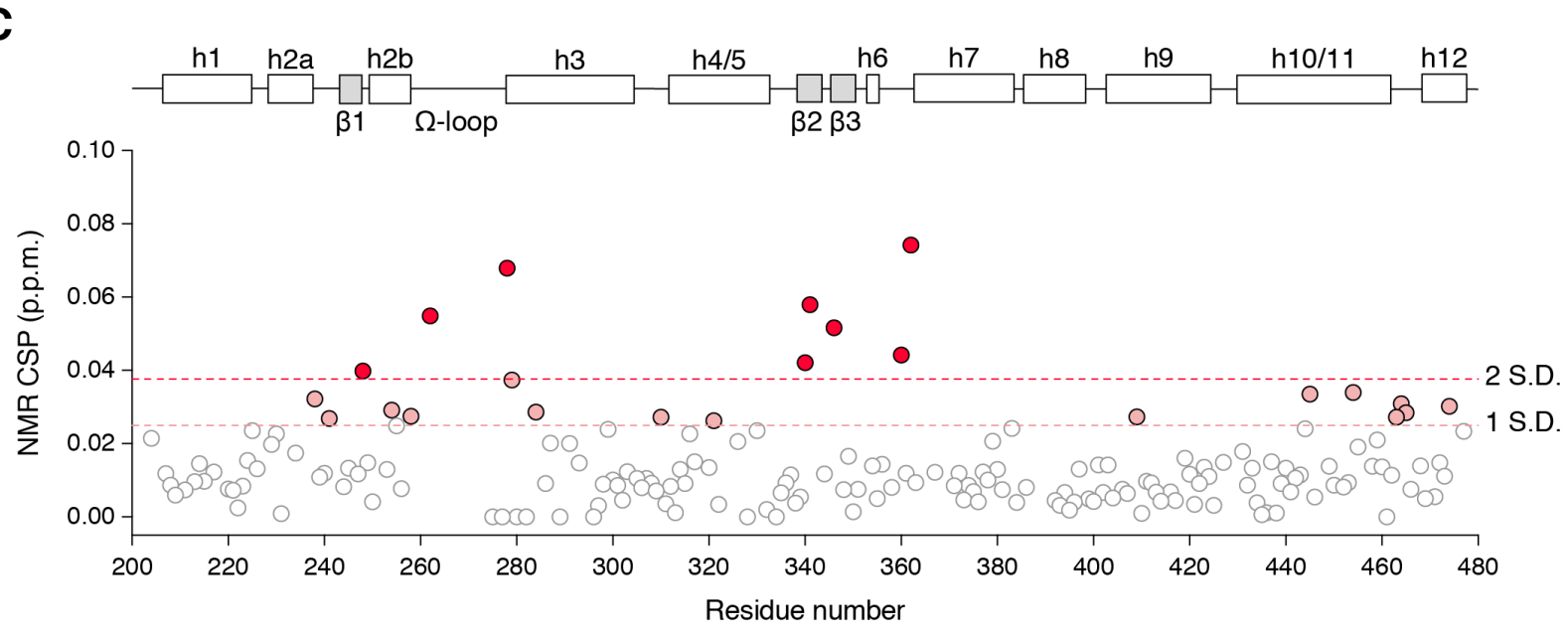

Figure 3. Differential NMR analysis of Pio- and PioOH-bound PPAR $\gamma$ LBD. (A) Overlay of $2 \mathrm{D}\left[{ }^{1} \mathrm{H},{ }^{15} \mathrm{~N}\right]-\mathrm{TROSY}-$ HSQC spectra ${ }^{15} \mathrm{~N}$-labeled PPAR $\gamma$ LBD $(200 \mu \mathrm{M})$ with 2 molar equivalents of Pio or PioOH. (B) Residues with NMR chemical shift perturbations (CSPs) greater than 1 S.D. from the average plotted on the PPAR $\gamma$ LBD with the Pio and PioOH ligands displayed as blue and magenta sticks, respectively. Blue dashed ovals indicate two regions with the most CSPs, the $\beta$-sheet region and the putative pocket entry/exit region. The dashed gray loop indicates the conformationally flexible $\Omega$-loop absent from in the crystal structures. Pio is shown in light blue and PioOH is shown in magenta. (C) NMR CSPs plotted by residue; residues are highlighted with CSPs $>1$ S.D. (pink dashed lines and circles) or 2 S.D. (red dashed line and circles) from the mean CSP (0.013 p.p.m.). PPAR $\gamma$ LBD structural elements are depicted linearly above the graph.

of PPAR $\gamma$ LBD (Fig. 3C), which can be due to differences in residues that directly contact the ligands as well as allosteric conformational differences that occur between Pio- and Pio- 
$\mathrm{OH}$ bound PPAR $\gamma$ LBD. There were eight residues with CSPs more than two standard deviations (CSP $>0.037$ p.p.m.) from the mean CSP (0.013 p.p.m.) (Fig. 3B,C). These residues were located primarily in the $\beta$-sheet region (L340, I341, G346, and V248) (Fig. 4A and B), or at the putative site of ligand entry/exit (29), a region comprised of the h6-7 loop (F360 and D362) and the N-terminus of h3 (A278 and I279) (Fig. 4C and D). Another residue with a significant CSP (I262) was located in the $\Omega$ loop, a flexible region between $\mathrm{h} 2$ and $\mathrm{h} 3$ absent from most PPAR $\gamma$ LBD crystal structures.

The CSPs between Pio and PioOH-bound PPAR $\gamma$ observed for the $\beta$-sheet region were consistent with the water-mediated hydrogen bond observed in the PioOH-bound crystal structure between the PioOH hydroxyl group and the Ser342 side chain, which is not present in the Pio-bound structure. Although the crystal structures only showed minor structural changes $(0.5-0.8 \AA)$ in the backbone and negligible side chain alterations, the watermediated hydrogen bond showed a pronounced effect on the chemical environment of residues this region as detected by NMR (Fig. 4A,B and 3B). At the same time, residues with CSPs near the h6-7 loop were reflected by structural changes in the crystal structures: there was a $0.8 \AA$ shift of the h6-7 loop toward h3 accompanied by a downward shift of similar magnitude for the F360 side chain, and the side chains of D362 and I279 side chains showed a $2.5 \AA$ shift (Fig. 4D). Together, the CSP data suggest that hydroxylation of Pio has the greatest effect on the conformation of the ligand entry/exit site and the $\beta$-strand region of the PPAR $\gamma$ LBD, but only some of these changes were apparent in the crystal structure.

In addition to providing information about conformational changes via CSP analysis, NMR spectra can offer insight into differences in protein dynamics between two ligand-bound forms. For example, in our differential NMR analysis, a change in NMR lineshape, or peak
A

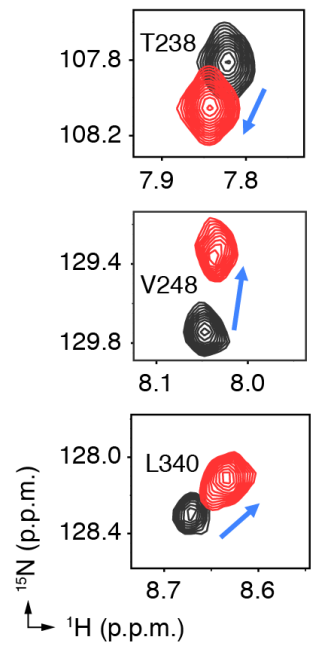

B

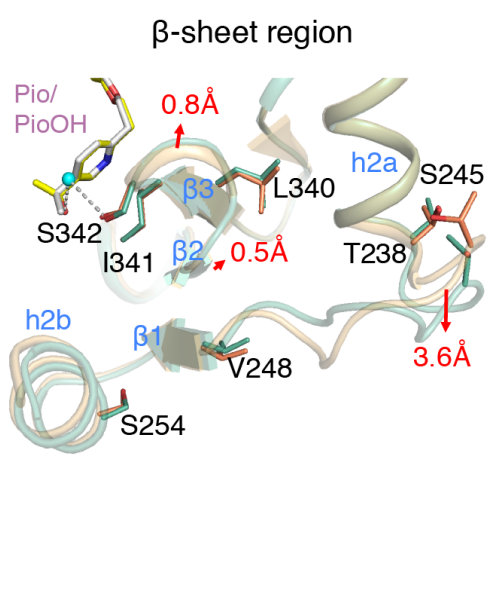

C

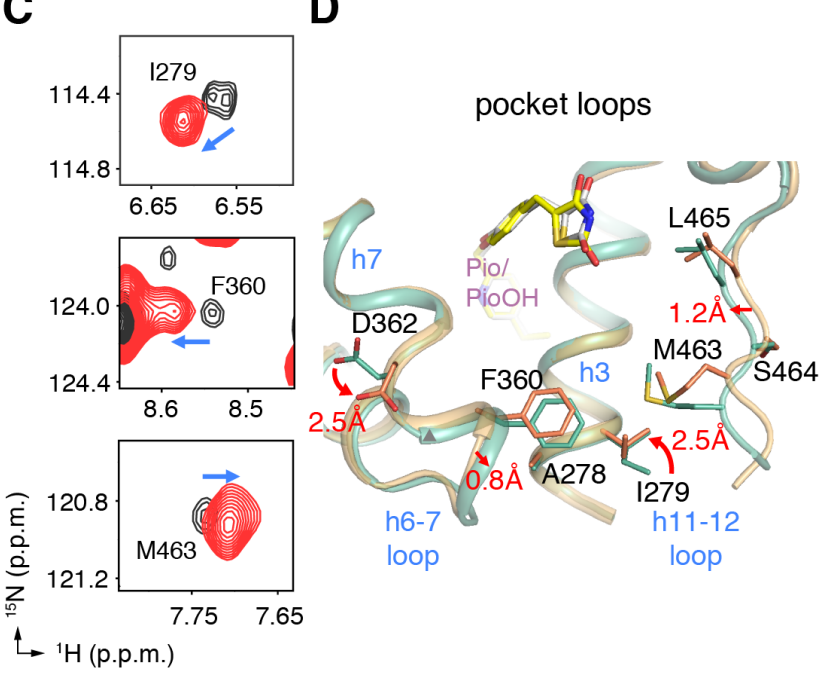

Figure 4. Correlation between differential NMR data and crystal structures. (A) Representative residues with notable NMR CSPs in the $\beta$-sheet region of the ligand-binding pocket. Blue arrows indicate the direction of the CSP from Pio (black peaks) to PioOH (red peaks). (B) Subtle conformational changes in $\beta$-strand region are observed in PPAR $\gamma$ LBD crystal structures bound to Pio (PDB code 5Y2O, chain A; light orange cartoon, white ligand) and PioOH (PDB code 6DHA, chain A; light green cartoon, yellow ligand). (C) Representative residues, depicted as in (A), with notable CSPs in the ligand entry/exit region of the ligand-binding pocket, which (D) also manifest as subtle conformational changes in ligand-bound crystal structures, as depicted in (B). 
bioRxiv preprint doi: https://doi.org/10.1101/351346; this version posted August 13, 2018. The copyright holder for this preprint (which was not certified by peer review) is the author/funder, who has granted bioRxiv a license to display the preprint in perpetuity. It is made available under aCC-BY 4.0 International license.

\section{Structure-function analysis of 1-hydroxypioglitazone}
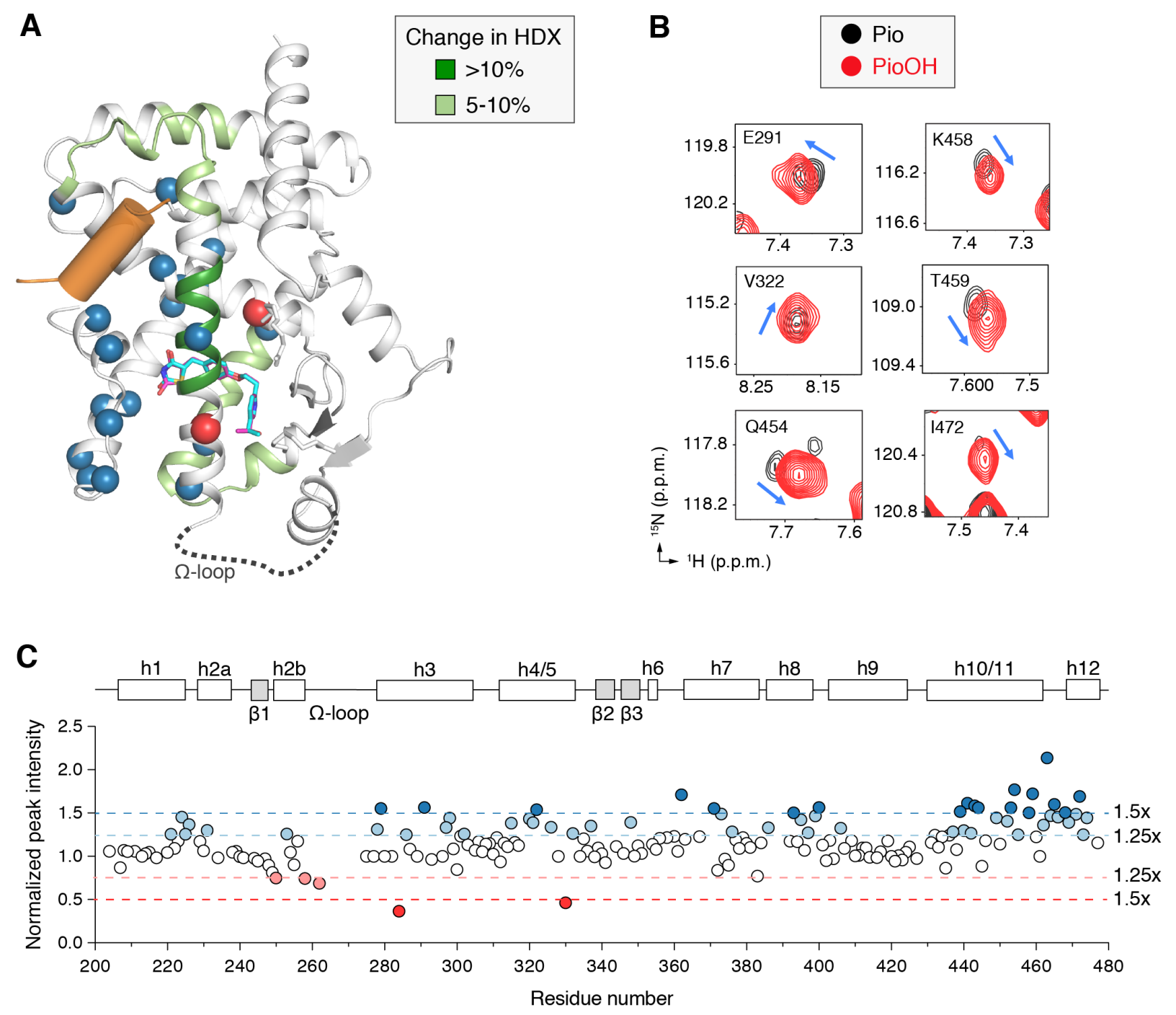

Figure 5. PioOH enhances stabilization of the AF-2 coregulator interaction surface. (A) Results of HDX-MS and NMR peak intensity analysis displayed on PPAR $\gamma$ LBD crystal structure with a coactivator peptide (orange cylinder) bound to the AF-2 surface (PDB code 2PRG, chain A); Pio and PioOH ligand binding modes are displayed as blue and magenta sticks, respectively. Regions of the PPAR $\gamma$ LBD that exhibit increased protection from HDX bound to PioOH relative to Pio are colored light or dark green on the cartoon diagram. Residues with increased (blue spheres) or decreased (red spheres) NMR peak intensity when PPAR $\gamma$ LBD is bound to PioOH, relative to PPAR $\gamma$ LBD bound to Pio, in the differential NMR analysis are also displayed. (B) Representative residues with increased NMR peak intensity in the PioOH-bound form relative to the Pio-bound form. (C) Differential NMR peak intensity analysis plotted by residue. PioOH-bound peak intensities are normalized to Pio-bound peak intensities; residues are highlighted with normalized peak intensities greater than (blue) or less than (red) $1.25 \mathrm{x}$ and $1.5 \mathrm{x}$ the average normalized peak intensity difference. PPAR $\gamma$ LBD structural elements are depicted linearly above the graph.

intensity, indicates a change in dynamics on the microsecond-millisecond ( $\mu \mathrm{s}-\mathrm{ms})$ timescale (i.e., intermediate exchange on the NMR timescale between two or more conformations). A number of residues in PioOH-bound PPAR $\gamma$ LBD showed an increase in NMR peak intensity compared to Pio-bound PPAR $\gamma$ LBD, indicating $\mathrm{PioOH}$ 
stabilized $\mu \mathrm{s}-\mathrm{ms}$ timescale dynamics introduced by Pio (Fig. 5A-C). Importantly, many of the stabilized residues were located at the AF-2 coactivator binding surface, indicating that $\mathrm{PioOH}$ may more effectively stabilize h12 docking against h3 and h11 in the AF-2 "active" conformation that is compatible with coactivator binding.

Whereas NMR lineshape analysis reports on $\mu \mathrm{s}-\mathrm{ms}$ timescale dynamics, HDX-MS probes molecular "breathing" motions or dynamics on a timescale of seconds (30). To determine whether the enhanced AF-2 stabilization observed for PioOH by NMR can be detected at longer timescales, we performed differential HDX-MS of PPAR $\gamma$ LBD bound to Pio or PioOH (Fig. 5A; Table S1). Consistent with our NMR analysis, PioOH afforded greater protection from deuterium exchange than Pio for peptides within h3 and the h3-h4/5 loop within the AF-2 surface. There was also stabilization of the h6-7 loop region, which exhibited significant NMR CSPs and stabilization of $\mu \mathrm{s}-\mathrm{ms}$ time scale dynamics when bound to PioOH, inferred by increased NMR peak intensities.

A

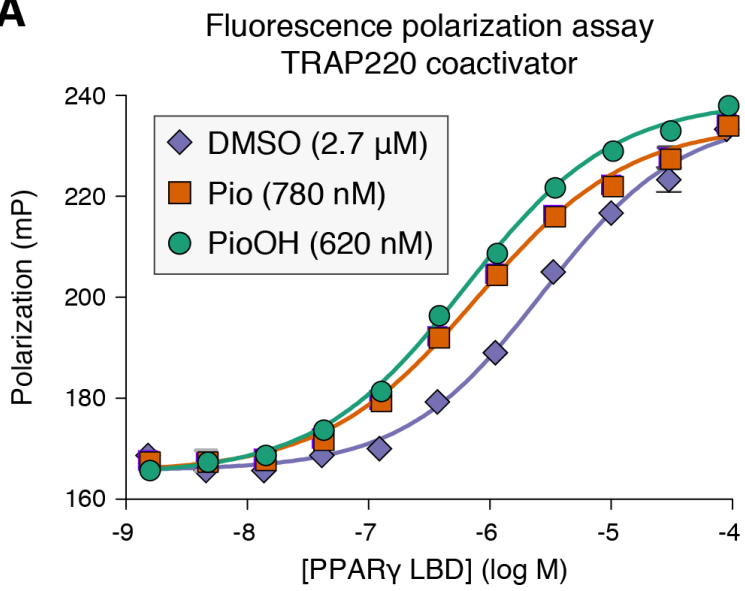

PioOH differentially affects coregulator binding mechanisms

Although our binding assays showed that PioOH is less potent than Pio, our NMR and HDX-MS analyses revealed that $\mathrm{PioOH}$ more effectively stabilizes the AF-2 surface. AF-2 stabilization is linked to enhanced functional agonism through higher affinity coactivator binding (31). To test this directly, we performed fluorescence polarization (FP) assays to determine how Pio hydroxylation affects the binding affinity of PPAR $\gamma$ LBD for the TRAP220 coactivator peptide. Compared to apo-PPAR $\gamma$ LBD, both ligands increased the affinity of the TRAP220 peptide relative to apo-PPAR $\gamma$ LBD. PioOH-bound PPAR $\gamma$ LBD consistently bound to the TRAP220 coactivator peptide with higher affinity than Pio-bound PPAR $\gamma$ LBD in each trial, but the difference in the fitted $K_{d}$ values did not achieve statistical significance $(\mathrm{P} \sim 0.1)$ (Fig. 6A).

We also tested the effect of PioOH vs. Pio on corepressor binding affinity. Using FP assays with a FITC-labeled NCoR1 corepressor peptide, we found that both ligands

B

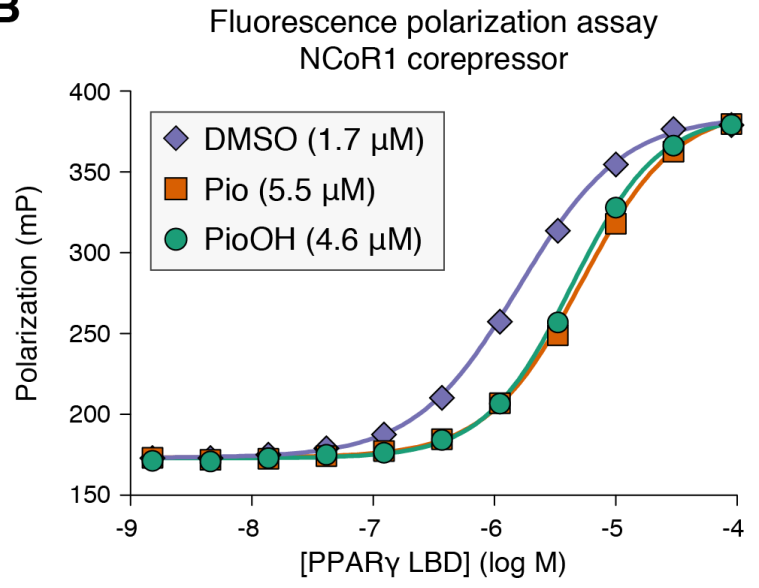

Figure 6. Pio hydroxylation affects coactivator and corepressor binding to PPAR $\gamma$ LBD. (A,B) Fluorescence polarization assays determined the binding affinities of FITC-labeled peptides derived from the (A) TRAP220 coactivator and (B) NCoR corepressor. Assays performed using a saturating amount of ligand, or vehicle control. 


\section{Structure-function analysis of 1-hydroxypioglitazone}

A

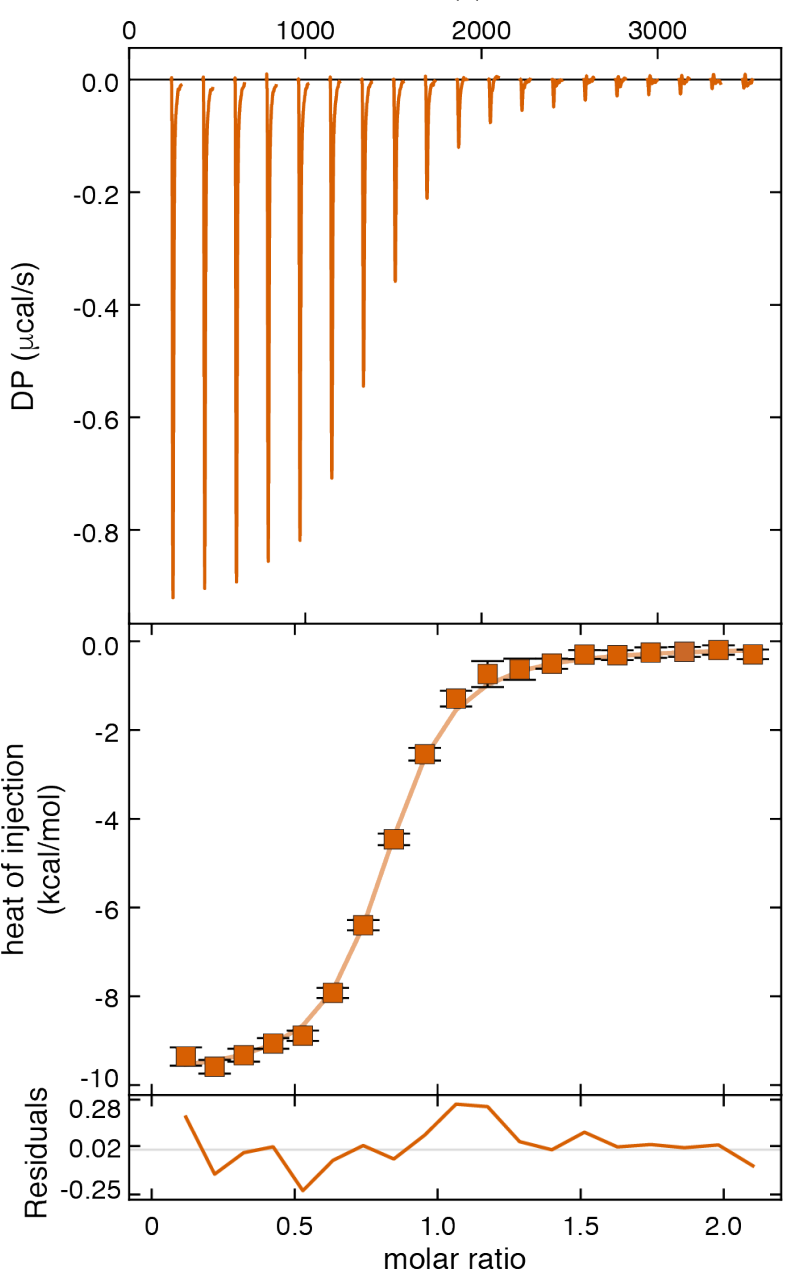

B

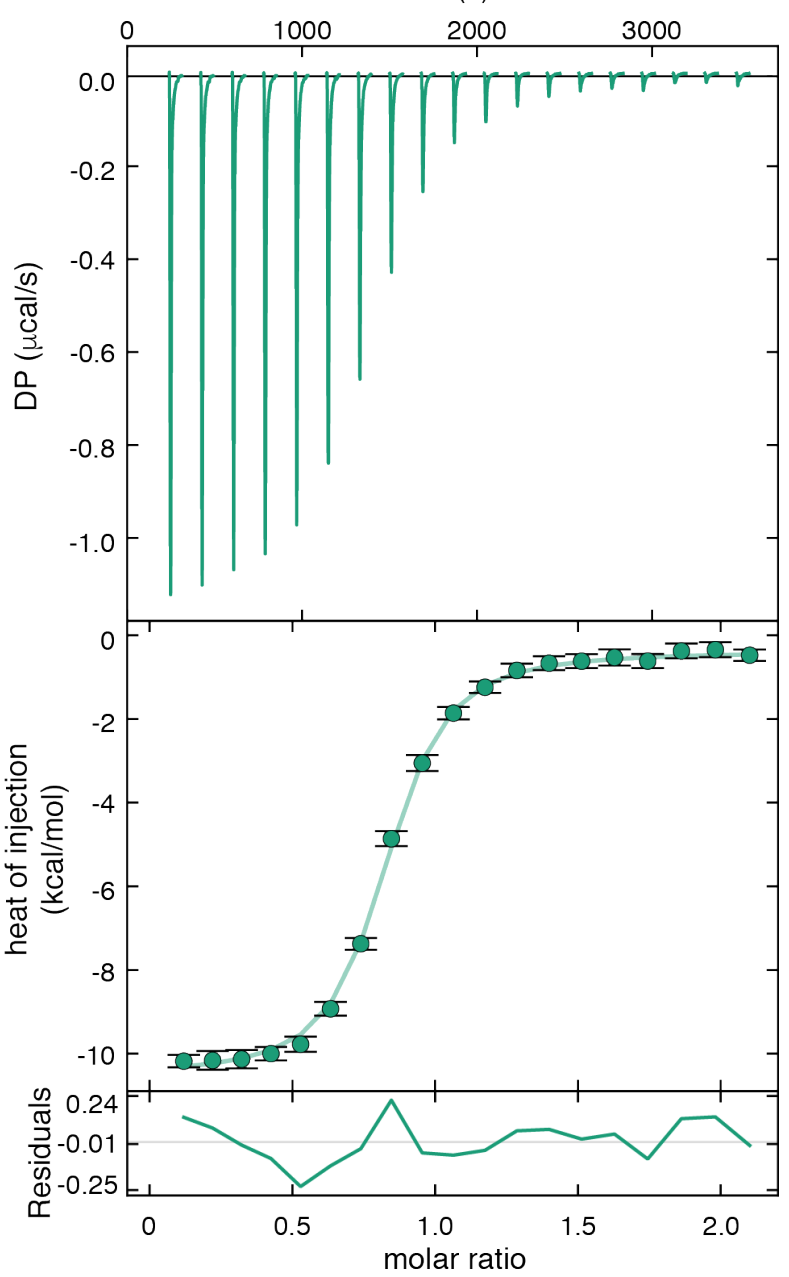

C

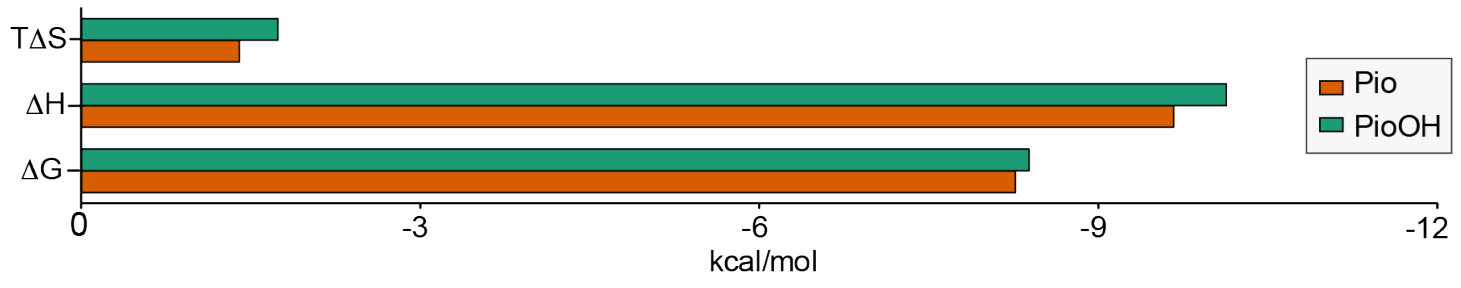

Figure 7. PioOH stabilizes coactivator binding to the PPARg LBD. (A,B) Representative thermograms and normalized plotted data from ITC analysis of TRAP220 binding to Pio- (A) or PioOH- (B) bound PPAR $\gamma$ LBD. (C) Fitted thermodynamic parameters from a global analysis of two replicate runs per condition.

reduced the affinity of the NCoR1 peptide relative to apo-PPAR $\gamma$ LBD (Fig. 6B). However, in this case PioOH was significantly less effective than Pio at reducing NCoR binding $(\mathrm{P}<0.001)$. Taken together, this indicates that although the ligand-dependent effects on coactivator and corepressor binding affinities may be related, where TZD agonists both strengthen TRAP220 coactivator affinity and weaken NCoR1 corepressor affinity relative to apo-PPAR $\gamma$, they are not directly correlated since the ligand that produced marginally improved TRAP220 coactivator affinity (PioOH) did not weaken NCoR1 corepressor affinity the most.

Although the FP assays did not reveal a 


\section{Structure-function analysis of 1-hydroxypioglitazone}

Table 2. Fitted isothermal titration calorimetry parameters for TRAP220 titrated into PPAR $\gamma$ LBD.

\begin{tabular}{l|l|l|l|l|} 
Ligand & $\mathrm{K}_{\mathrm{d}}(\mathrm{nM})$ & $\begin{array}{l}\Delta \mathrm{G} \\
(\mathrm{kcal} / \mathrm{mol})\end{array}$ & $\Delta \mathrm{H}(\mathrm{kcal} / \mathrm{mol})$ & $\Delta \mathrm{S}\left(\mathrm{kcal} / \mathrm{mol}^{*} \mathrm{~K}\right)$ \\
\hline Pio & $\begin{array}{l}871 \\
(68.3 \% \mathrm{CI}: 740 \text { to } 1020)\end{array}$ & -8.39 & $\begin{array}{l}-10.136 \\
(68.3 \% \mathrm{CI}:-10.3589 \text { to }-9.9186)\end{array}$ & -5.856 \\
\hline PioOH & $\begin{array}{l}708 \\
(68.3 \% \mathrm{CI}: 606 \text { to } 823)\end{array}$ & -8.27 & $\begin{array}{l}-9.668 \\
(68.3 \% \mathrm{CI}:-9.8940 \text { to } 9.4541)\end{array}$ & -4.669 \\
\hline
\end{tabular}

significantly enhanced coactivator binding affinity, the polarization window for TRAP220 binding produced by $\mathrm{PioOH}$ was consistently greater than that of Pio $(\mathrm{P}<0.05)$, suggesting a greater reduction in molecular tumbling or better stabilization of peptide binding, perhaps via better AF-2 stabilization, at saturating conditions. To test the thermodynamic basis of this observation, we performed isothermal titration calorimetry using the unlabeled TRAP220 peptide and the PPAR $\gamma$ LBD bound to two molar equivalents of either Pio or PioOH (Fig. 7A and B). Consistent with the FP assay, the $\mathrm{K}_{\mathrm{d}}$ of peptide binding was lower for PioOHbound PPAR $\gamma$, but did not achieve statistical significance; however, the enthalpy $(\Delta \mathrm{H})$ of binding was significantly reduced compared to Pio, suggesting stabilized electrostatic contacts with TRAP220 when bound to PioOH (Table 2 and Fig. 7C). Additionally, the entropy $(\Delta S)$ of binding was more negative and thus less favorable for $\mathrm{PioOH}$, indicating that the binding dynamics between TRAP220 and PioOH-bound PPAR $\gamma$ LBD are less flexible than for the Pio-bound structure.

\section{PioOH enhances the transcriptional activity of the PPAR $\mathrm{LBD}$}

To compare the cellular activation properties of Pio and PioOH, we performed transcriptional reporter assays by transfecting HEK293T cells with an expression plasmid encoding full-length PPAR $\gamma$ along with a reporter plasmid containing three copies of the PPAR DNA response element (3xPPRE) upstream of the luciferase gene. Both Pio and PioOH caused a concentration-dependent increase in PPAR $\gamma$ transcription, and consistent with the biochemical binding data $\mathrm{PioOH}$ showed reduced cellular potency relative to $\mathrm{Pio}$ $(\mathrm{P}<0.0001)$ (Fig. 8A).

We also performed a cell-based transcriptional reporter assay using a chimeric expression construct comprised of the PPAR $\gamma$ LBD fused to the Gal4 yeast transcription factor DBD. This construct lacks the Nterminal ligand-independent activation function-1 (AF-1) and native DNA-binding domain in PPAR $\gamma$ and thus reports on LBD activity only, and provides a higher window of activation and is therefore more sensitive to graded levels of agonism (11) compared to the full-length PPAR $\gamma$ assay. We transfected HEK293T cells with the Gal4-PPAR $\gamma$ LBD expression plasmid and a reporter plasmid containing five tandem repeats of the Gal4 Upstream Activation Sequence (5xUAS) placed upstream of the luciferase gene. Consistent with the full-length PPAR $\gamma$ results, PioOH was less potent than $\mathrm{Pio}(\mathrm{P}<0.02)$ (Fig. 8B). Intriguingly, however, $\mathrm{PioOH}$ yielded a significantly greater maximal luciferase activity than Pio $(\mathrm{P}<0.05)$. Thus, enhanced AF2 surface stabilization afforded by $\mathrm{PioOH}$ corresponds to increased transcriptional activition of the LBD-only construct, which 


\section{Structure-function analysis of 1-hydroxypioglitazone}

A

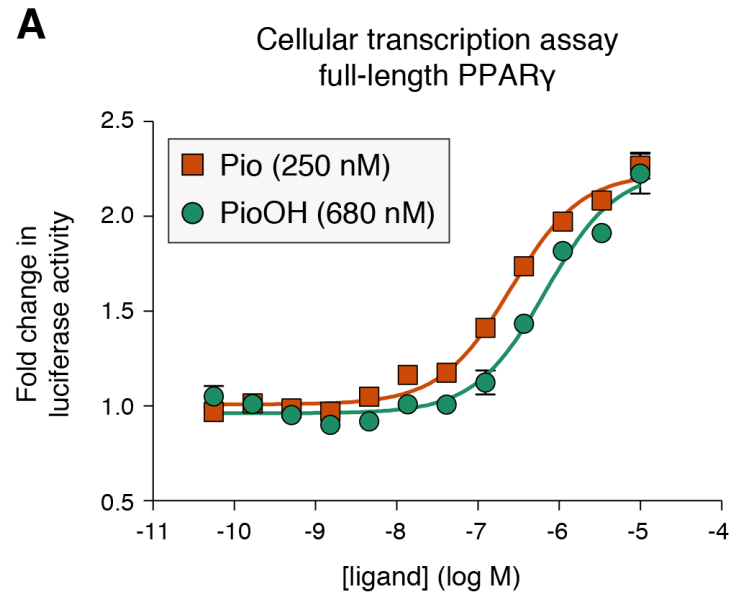

B

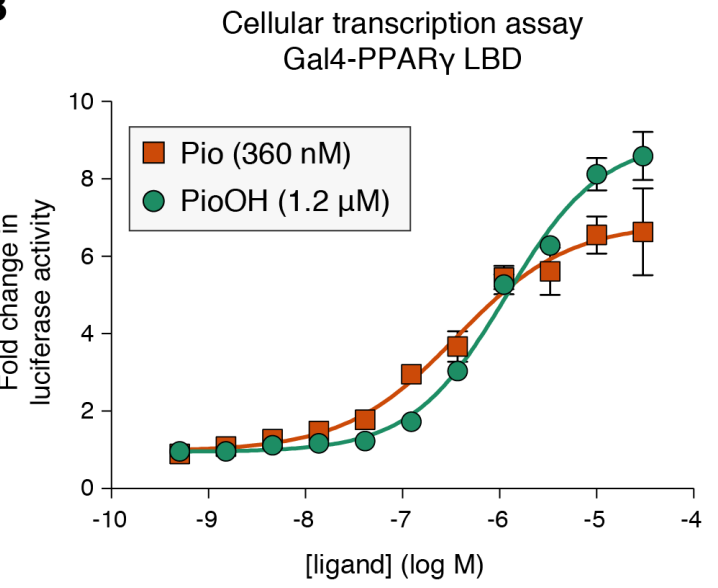

Figure 8. PioOH induces a modestly greater transcriptional efficacy of the PPAR $\gamma$ LBD. (A) Full-length PPAR $\gamma$ luciferase transcriptional assay using a 3xPPRE-luciferase reporter plasmid in HEK293T cells treated with increasing concentrations of Pio or PioOH; data are normalized to DMSO control treated cells. (B) PPAR $\gamma$ LBD-Gal4 DBD luciferase transcriptional assay using a 5xUAS-luciferase reporter plasmid in HEK293T cells treated with increasing concentrations of Pio or PioOH; data are normalized to DMSO control treated cells. Ligand $\mathrm{EC}_{50}$ values for cellular transcriptional activation are shown in the legends.

may not be apparent in the full-length assay due to lower sensitivity or contributions of the Nterminal ligand-independent AF-1 domain.

\section{DISCUSSION}

Pioglitazone (brand/trade name Actos) remains an important option for treatment of T2DM because of its potent insulin sensitizing effects $(32,33)$. However, adverse side effects have warranted further investigation into its mechanism of action. To our knowledge, little is known how Pio metabolites, or the metabolites of any other PPAR $\gamma$-binding drug, affect the structure and function of PPAR $\gamma$. Therefore, we performed a comparative structure-function analysis of Pio and its major in vivo Pio metabolite, 1-hydroxypioglitazone (PioOH), using X-ray crystallography and solution-state structural methods in combination with biochemical and cell-based assays. We found that PioOH binds PPAR $\gamma$ with weaker affinity than Pio, but produces a modestly more efficacious agonist response at saturating ligand conditions in biochemical
(TR-FRET) and cellular (chimeric Gal4 transactivation) assays, potentially due to stabilization of an LBD conformation with enhanced coactivator binding affinity. Crystal structures of PPAR $\gamma$ LBD bound to Pio and PioOH did not show any overall structural changes that could lead to the improved agonist profile of PioOH. However, solution-state structural analysis using NMR spectroscopy and HDX-MS revealed that $\mathrm{PioOH}$ better stabilizes the dynamics of the AF-2 surface, which is consistent with its improved biochemical, thermodynamic, and cellular agonist features over Pio on LBD activity. Because Pio and $\mathrm{PioOH}$ concentrations are similar in human serum (23), the reduced potency of PioOH likely underlies its reduced anti-hyperglycemic efficacy relative to Pio $(25,26)$. If $\mathrm{PioOH}$ serum concentrations were higher than Pio, it is possible that $\mathrm{PioOH}$ would be nearly as efficacious as Pio.

Analysis of the metabolites of other nuclear receptor ligands has provided essential insight to into the activity of the parent compound/drug and informed the design of 


\section{Structure-function analysis of 1-hydroxypioglitazone}

small molecule therapeutics. For example, testosterone is the primary endogenous ligand of androgen receptor (AR), but in tissues expressing $5 \alpha$-reductase, testosterone is converted to $5 \alpha$-dihydrotestosterone ( $5 \alpha$ DHT), which binds with greater selectivity and affinity to $\mathrm{AR}$ and is thought to enhance androgenic effects in specific tissues such as the prostate and seminal vesicles (34). Intriguingly, $5 \alpha$-DHT differs from testosterone only by the presence of an additional unsaturated double bond and, similar to our analysis here of PPAR $\gamma$, crystal structures of AR LBD bound to $5 \alpha$-DHT or testosterone revealed no large structural changes (overall C $\alpha$ RMSD only $0.238 \AA$ ) that would lead to improved function (35). However, comprehensive analysis of atomic geometries within the AR ligand-binding pocket revealed the subtle interactions in the two liganded complexes that determine AR ligand affinity. These findings and others informed the development of selective androgen receptor modulators (SARMs) with more favorable ratios of anabolic to androgenic effects $(36,37)$

Drug metabolite studies have also informed the development of selective estrogen receptor modulators (SERMs). Pharmacokinetic analysis revealed that the metabolites of tamoxifen had variable activity at Estrogen Receptor (ER): 4hydroxytamoxifen and N-desmethyl-4hydroxytamoxifen (endoxifen) exhibited 100fold greater affinity and were found to underlie tamoxifen's ability to antagonize ER in breast cancer tissue $(38,39)$. Another metabolite of tamoxifen was found to have weak antiestrogenic activity, and equivalent chemical modifications were made to the SERM Toremifene to produce Ospemifene, a SERM with promising anti-tumor and probone growth effects (40). Ultimately, structural studies probing the molecular and biophysical basis of ER-metabolite interactions have contributed to SERM identification and characterization $(39,41)$.

Efforts to develop selective PPAR modulators (SPPARMs) have been underway for over a decade (42). Recent work has focused on separating the "classical" agonist effects of PPAR $\gamma$-binding ligands from their ability to regulate "non-classical" posttranslational modifications of PPAR $\gamma(19,43)$. Here, our work indicates that the introduction of a water-mediated hydrogen bonding network underlies the weakened binding affinity of $\mathrm{PioOH}$ relative to Pio. This was somewhat unexpected because the hydrogen bonding ability introduced by the addition of the hydroxyl group in $\mathrm{PioOH}$ in an otherwise hydrophobic ligand side-chain (in Pio) would typically be considered as overall favorable for binding affinity, but underlies the notion that hydrophobic effects also play an important role in ligand binding affinity (44). However, although $\mathrm{PioOH}$ displayed weaker binding affinity to Pio, our solution-based structural analysis revealed that $\mathrm{PioOH}$ better stabilized several regions of the LBD than Pio. The stabilized regions include the AF-2 coregulator surface and a region of helix 7 that includes a ligand-dependent SUMOylation site (Lys367) implicated in promoting PPAR $\gamma$-mediated repression of pro-inflammatory genes (45). The water-mediated hydrogen bond observed between PioOH and S342 side-chain in our crystal structure was confirmed by our NMR studies, which showed conformational changes via chemical shift changes for residues within the $\beta$-sheet region of the ligand-binding pocket. Ligand interactions with the backbone amide of Ser342 have previously been implicated in inhibiting the phosphorylation of S273 (S245 in PPAR $\gamma$ isoform 1), which is associated with obesogenic side effects of PPAR $\gamma$ activation $(18,19)$. Thus, it will be interesting to determine in future studies if the Pio metabolite, $\mathrm{PioOH}$, enhances the non-classical effects of Pio on PPAR $\gamma$ activity. Taken together, our findings provide new insight into 
how structure-function studies of PPAR $\gamma$ binding drug metabolites may help to inform on the function and design of PPAR $\gamma$ ligands.

\section{EXPERMIENTAL PROCEDURES}

\section{Ligands and protein preparation}

Pioglitazone (Pio; Cayman Chemical) and 1-hydroxypioglitazone (PioOH; Axon Medchem) were prepared in DMSO-d 6 as 50 $\mathrm{mM}$ and $7 \mathrm{mM}$ stocks, respectively. Human PPAR $\gamma$ LBD (residues 203-477, isoform 1 numbering) was expressed in Escherichia coli BL21(DE3) cells as TEV-cleavable hexahistidine (6xHis)-tagged fusion protein using protocols previously described $(11,12)$. Purified protein was delipidated using LIPIDEX 1000 resin (Perkin Elmer) and stored in $20 \mathrm{mM}$ potassium phosphate $(\mathrm{pH} 7.4), 50$ $\mathrm{mM}$ potassium chloride, $0.5 \mathrm{mM}$ EDTA, and 5 $\mathrm{mM}$ TCEP. FITC-labeled peptides derived from the TRAP220 coactivator (residues 638656; NTKNHPMLMNLLKDNPAQD) and NCoR1 corepressor (residues 2256-2278; DPASNLGLEDIIRKALMGSFDDK) were synthesized by Lifetein; peptides contained a six-carbon linker (Ahx) after the FITC label, and the $\mathrm{C}$ terminus was amidated for stability.

\section{Circular dichroism (CD) spectroscopy}

CD wavelength scans and thermal denaturation experiments monitored at $222 \mathrm{~nm}$ were performed in CD buffer $(10 \mathrm{mM}$ potassium phosphate $(\mathrm{pH} 7.4)$ and $50 \mathrm{mM}$ potassium fluoride) to determine the folding and stability of PPAR $\gamma$ LBD $(10 \mu \mathrm{M})$ in the presence of one molar equivalent of Pio or PioOH on a Jasco J-815 spectropolarimeter.

\section{TR-FRET competitive ligand displacement and coregulator interaction assays}

Time-resolved fluorescence resonance energy transfer (TR-FRET) assays were performed in black low-volume 384-well plate (Greiner) using a buffer containing $20 \mathrm{mM}$ potassium phosphate ( $\mathrm{pH}$ 7.4), $50 \mathrm{mM}$ potassium chloride, $0.5 \mathrm{mM}$ EDTA, and $5 \mathrm{mM}$ TCEP, and $0.01 \%$ Tween-20. For the ligand displacement assay, each well $(22.5 \mu \mathrm{L}$ per well) contained $1 \mathrm{nM}$ 6xHis-PPAR $\gamma$ LBD protein, $1 \mathrm{nM}$ LanthaScreen Elite Tb-anti-His Antibody (Thermo Fisher Scientific), and $5 \mathrm{nM}$ Fluormone Pan-PPAR Green tracer ligand (Invitrogen) in TR-FRET buffer. For the TRFRET coregulator interaction assay, each well contained $400 \mathrm{nM}$ FITC-labeled TRAP220 or NCoR1 peptides, $4 \mathrm{nM}$ 6xHis-PPAR $\gamma$ LBD protein, $1 \mathrm{nM}$ LanthaScreen Elite Tb-anti-His Antibody (Thermo Fisher Scientific), and 400 $\mathrm{nM}$ peptide in TR-FRET buffer in $22.5 \mu \mathrm{L}$ total volume per well. Ligand stocks were prepared via serial dilution in DMSO, added to wells in triplicate to a final DMSO concentration of $1 \%$, and the plates were incubated at $25^{\circ} \mathrm{C}$ for $\sim 1 \mathrm{~h}$ and read using BioTek Synergy Neo multimode plate reader. The $\mathrm{Tb}$ donor was excited at $340 \mathrm{~nm}$; its fluorescence emission was monitored at $495 \mathrm{~nm}$, and the acceptor FITC emission was measured at $520 \mathrm{~nm}$. The TR-FRET ratio was calculated as the signal at $520 \mathrm{~nm}$ divided by the signal at $495 \mathrm{~nm}$. Data were plotted using GraphPad Prism and fit to the appropriate equation: for the ligand displacement assay, data were fit to a competitive one site fit $\mathrm{K}_{\mathrm{i}}$ equation using the known binding affinity of Fluormone ${ }^{\mathrm{TM}}$ PanPPAR Green tracer ligand $(2.8 \mathrm{nM}$; Thermo Fisher Scientific product insert PV4894); and for the coregulator interaction assay data were fit to a sigmoidal dose response equation.

\section{Cell-based transactivation assays}

HEK293T cells (ATCC; cat\# CRL-3216) cultured in DMEM media (Gibco) supplemented with $10 \%$ fetal bovine serum (FBS) and 50 units $\mathrm{mL}^{-1}$ of penicillin, streptomycin, and glutamine were grown to $90 \%$ confluency in a T-75 flask before seeding 4 million cells per well in 10-cm dishes. Seeded cells were transfected using transfection reagent containing $27 \mu \mathrm{L}$ X-treme Gene 9 
(Roche) in serum-free Opti-mem reduced serum media (Gibco) with either $4.5 \mu \mathrm{g}$ pCMV6-XL4 plasmid containing full-length human PPAR $\gamma 2$ and $4.5 \mu \mathrm{g} 3 \mathrm{X}$ multimerized PPRE-luciferase reporter or $4.5 \mu \mathrm{g}$ Gal4PPAR $\gamma$ LBD and $4.5 \mu \mathrm{g}$ 5X Upstream Activation Sequence (UAS) luciferase reporter. After $18 \mathrm{hrs}$ incubation at $37^{\circ} \mathrm{C}$ in a $5 \% \mathrm{CO}_{2}$ incubator, the transfected cells were plated in quadruplicate in white 384-well plates (Perkin Elmer) at a density of 10,000 cells per well (20 $\mu \mathrm{L}$ volume) and incubated $4 \mathrm{hrs}$ then treated with $20 \mu \mathrm{L}$ of vehicle control $(1 \%$ DMSO in DMEM media) or 1:2 serial dilution of each compound from 56 pM-10 $\mu \mathrm{M}(1 \%$ final DMSO concentration). After $18 \mathrm{hrs}$, luciferase activity was measured by addition of $20 \mu \mathrm{L}$ Britelite Plus (Perkin Elmer) and luminescence was read using a BioTek Synergy Neo multimode plate reader. Data were plotted in GraphPad Prism as fold change in luminescence of compound-treated cells over DMSO-treated control cells vs ligand concentration and fit to a sigmoidal dose response equation.

\section{Fluorescence polarization coregulator interaction assays}

Fluorescence polarization assays were performed in black low-volume 384-well plates (Greiner) using a buffer containing 20 $\mathrm{mM}$ potassium phosphate $(\mathrm{pH} 7.4), 50 \mathrm{mM}$ potassium chloride, $0.5 \mathrm{mM}$ EDTA, $5 \mathrm{mM}$ TCEP, and $0.01 \%$ Tween-20. Each well contained 100 nM FITC-labeled TRAP220 coactivator peptide (Lifetein), a serial dilution of PPAR $\gamma$ LBD $(1.5 \mathrm{nM}-90 \mu \mathrm{M})$, with a fixed concentration of vehicle control (1\% DMSO) or ligand equal to the highest protein concentration $(90 \mu \mathrm{M}$ Pio or $\mathrm{PioOH})$ in triplicate. Plates were incubated $2 \mathrm{hrs}$ at $4^{\circ} \mathrm{C}$ and read using BioTek Synergy Neo multimode plate reader. Data were plotted in GraphPad Prism and fit to a sigmoidal dose response equation.

\section{Statistical Tests}

Statistical significance between best fit $\mathrm{EC}_{50}, \mathrm{IC}_{50}$, and top values in biochemical and cell-based assays was determined using the GraphPad Prism Extra sum-of-squares F test analysis with alpha equal to 0.05 .

\section{Isothermal titration calorimetry}

A peptide derived from the TRAP220 coactivator (residues 638-656; NTKNHPMLMNLLKDNPAQD) was synthesized by Lifetein and resuspended at 500 $\mu \mathrm{M}$ in buffer containing $20 \mathrm{mM}$ potassium phosphate ( $\mathrm{pH}$ 7.4), $50 \mathrm{mM}$ potassium chloride, $0.5 \mathrm{mM}$ EDTA, and $5 \mathrm{mM}$ TCEP. PPAR $\gamma$ LBD was prepared at $50 \mu \mathrm{M}$ in identical buffer. $100 \mu \mathrm{M}$ Pio or PioOH were added to PPAR $\gamma$ LBD and TRAP220 and incubated on ice 30 minutes before each experiment. TRAP220 peptide (syringe) was titrated into PPARg LBD (sample cell). 20 total injections were made per experiment $(0.4 \mu \mathrm{L}$ for the first injection, $2.0 \mu \mathrm{L}$ for subsequent injections), using a mixing speed of $1200 \mathrm{rpm}$, a reference power of $5 \mu \mathrm{cal} / \mathrm{second}$, and a cell temperature of $25^{\circ} \mathrm{C}$. Two runs were performed for each ligand-bound condition. Experiments were performed using a MicroCal iTC200 (Malvern). Data were processed in NITPIC (46) and analyzed by unbiased global fitting of both replicate runs per ligand-bound condition in SEDPHAT (47), followed by export to GUSSI for publication-quality figure preparation (48).

\section{NMR spectroscopy}

Two dimensional $\left[{ }^{1} \mathrm{H},{ }^{15} \mathrm{~N}\right]$-transverse relaxation optimized spectroscopy (TROSY)heteronuclear single quantum correlation (HSQC) data were collected at 298K using a Bruker $700 \mathrm{Mhz}$ NMR instrument equipped with a QCI cryoprobe. Samples contained 200 $\mu \mathrm{M}{ }^{15} \mathrm{~N}$-labeled PPAR $\gamma$ LBD in a buffer (NMR buffer) containing $20 \mathrm{mM}$ potassium phosphate ( $\mathrm{pH} 7.4), 50 \mathrm{mM}$ potassium chloride, $0.5 \mathrm{mM}$ 
EDTA, $5 \mathrm{mM}$ TCEP, and $10 \% \mathrm{D}_{2} \mathrm{O}$ in the absence or presence of two molar equivalents of Pio or PioOH. Data were processed and analyzed using Topspin 3.0 (Bruker) and NMRViewJ (OneMoon Scientific, Inc.) (49). NMR analysis was performed using previously described rosiglitazone-bound NMR chemical shift assignments (BMRB entry 17975) for well resolved residues with consistent NMR peak positions via the minimum chemical shift procedure $(11,28)$.

\section{X-ray crystallography}

PPAR $\gamma$ LBD was incubated with 1hydroxypioglitazone at a 1:3 protein/ligand molar ratio in PBS overnight before being concentrated to $10 \mathrm{mg} / \mathrm{ml}$. Crystals were obtained after $7-10$ days at $22^{\circ} \mathrm{C}$ by sittingdrop vapor diffusion against $50 \mu \mathrm{L}$ of well solution. The crystallization drops contain $1 \mu \mathrm{L}$ of protein sample mixed with $1 \mu \mathrm{L}$ of reservoir solution containing $0.1 \mathrm{M}$ Tris- $\mathrm{HCl}, 0.8 \mathrm{M}$ sodium citrate at $\mathrm{pH}$ 7.6. Crystals were flashcooled in liquid nitrogen before data collection. Data collection was carried out at Beamline 5.0.2 at Berkeley Center for Structural Biology (Advanced Light Source). Data were processed, integrated, and scaled with the programs Mosflm and Scala in CCP4 (50,51). The structure was solved at $1.88 \AA$ by molecular replacement using the program Phaser (52) that was implemented in the PHENIX package (53) using a previously published PPAR $\gamma$ LBD crystal structure (PDB code: 1PRG (54)) as the search model. The structure was refined using PHENIX with several cycles of interactive model rebuilding in COOT (55).

\section{Hydrogen-deuteirum exchange mass spectrometry (HDX-MS)}

Solution-phase amide HDX experiments were carried out with a fully automated system described previously (56) with slight modifications. Five $\mu$ l of PPAR $\gamma$ LBD protein $(10 \mu \mathrm{M})$, without or with Pio or PioOH (100 $\mu \mathrm{M})$, was mixed with $20 \mu \mathrm{L}$ of $\mathrm{D}_{2} \mathrm{O}$-containing NMR buffer and incubated at $4{ }^{\circ} \mathrm{C}$ for a range of time points $(0 \mathrm{~s}, 10 \mathrm{~s}, 30 \mathrm{~s}, 60 \mathrm{~s}, 900 \mathrm{~s}$ or $3,600 \mathrm{~s})$. Following exchange, unwanted forward or back exchange was minimized and the protein was denatured with a quench solution ( $5 \mathrm{M}$ urea, $50 \mathrm{mM}$ TCEP and $1 \% \mathrm{v} / \mathrm{v}$ TFA) at 1:1 ratio to protein. Samples were then passed through an in-house prepared immobilized pepsin column at $50 \mu \mathrm{L}$ min $^{-1}$ $\left(0.1 \% \mathrm{v} / \mathrm{v}\right.$ TFA, $\left.15{ }^{\circ} \mathrm{C}\right)$ and the resulting peptides were trapped on a $\mathrm{C}_{18}$ trap column (Hypersil Gold, Thermo Fisher). The bound peptides were then gradient-eluted (5-50\% $\mathrm{CH}_{3} \mathrm{CN}$ w/v and $0.3 \% \mathrm{w} / \mathrm{v}$ formic acid) across a $1 \mathrm{~mm} \times 50 \mathrm{~mm} \mathrm{C}_{18}$ HPLC column (Hypersil Gold, Thermo Fisher) for $5 \mathrm{~min}$ at $4{ }^{\circ} \mathrm{C}$. The eluted peptides were then analyzed directly using a high resolution Orbitrap mass spectrometer (Q Exactive, Thermo Fisher). Each HDX experiment was performed in triplicate. To identify peptides, MS/MS experiments were performed with a Q Exactive mass spectrometer over a 70 min gradient. Product ion spectra were acquired in a datadependent mode and the five most abundant ions were selected for the product ion analysis. The MS/MS *.raw data files were converted to *.mgf files and then submitted to Mascot (Matrix Science, London, UK) for peptide identification. Peptides with a Mascot score of 20 or greater were included in the peptide set used for HDX detection. The MS/MS Mascot search was also performed against a decoy (reverse) sequence and false positives were ruled out. The MS/MS spectra of all the peptide ions from the Mascot search were further manually inspected and only the unique charged ions with the highest Mascot score were used in estimating the sequence coverage. The intensity weighted average $\mathrm{m} / \mathrm{z}$ value (centroid) of each peptide isotopic envelope was calculated with the latest version of our inhouse developed software, HDX Workbench (57). 
bioRxiv preprint doi: https://doi.org/10.1101/351346; this version posted August 13, 2018. The copyright holder for this preprint (which was not certified by peer review) is the author/funder, who has granted bioRxiv a license to display the preprint in perpetuity. It is made available under aCC-BY 4.0 International license.

\section{Structure-function analysis of 1-hydroxypioglitazone}

\section{CONFLICT OF INTEREST}

The authors declare that they have no conflicts of interest with the contents of this article.

\section{REFERENCES}

1. Guan, H. P., Ishizuka, T., Chui, P. C., Lehrke, M., and Lazar, M. A. (2005) Corepressors selectively control the transcriptional activity of PPARgamma in adipocytes. Genes \& development 19, 453-461

2. $\quad$ Ahmadian, M., Suh, J. M., Hah, N., Liddle, C., Atkins, A. R., Downes, M., and Evans, R. M. (2013) PPARgamma signaling and metabolism: the good, the bad and the future. Nat Med 19, 557-566

3. Moore, J. T., Collins, J. L., and Pearce, K. H. (2006) The nuclear receptor superfamily and drug discovery. ChemMedChem 1, 504-523

4. Tugwood, J. D., Issemann, I., Anderson, R. G., Bundell, K. R., McPheat, W. L., and Green, S. (1992) The mouse peroxisome proliferator activated receptor recognizes a response element in the $5^{\prime}$ flanking sequence of the rat acyl CoA oxidase gene. EMBO J 11, 433439

5. Helledie, T., Grontved, L., Jensen, S. S., Kiilerich, P., Rietveld, L., Albrektsen, T., Boysen, M. S., Nohr, J., Larsen, L. K., Fleckner, J., Stunnenberg, H. G., Kristiansen, K., and Mandrup, S. (2002) The gene encoding the Acyl-CoA-binding protein is activated by peroxisome proliferator-activated receptor gamma through an intronic response element functionally conserved between humans and rodents. J Biol Chem 277, 26821-26830

6. Meijsing, S. H., Pufall, M. A., So, A. Y., Bates, D. L., Chen, L., and Yamamoto, K. R. (2009) DNA Binding Site Sequence Directs Glucocorticoid Receptor Structure and Activity. Science (New York, N.Y.) 324, 407-410

7. de Vera, I. M. S., Zheng, J., Novick, S., Shang, J., Hughes, T. S., Brust, R., Munoz-Tello, P., Gardner, W. J., Jr., Marciano, D. P., Kong, X., Griffin, P. R., and Kojetin, D. J. (2017) Synergistic Regulation of Coregulator/Nuclear Receptor Interaction by Ligand and DNA. Structure 25, 1506-1518.e1504

8. Moore, T. W., Mayne, C. G., and Katzenellenbogen, J. A. (2010) Minireview: Not picking pockets: nuclear receptor alternate-site modulators (NRAMs). Mol Endocrinol 24, 683-695

9. Nolte, R. T., Wisely, G. B., Westin, S., Cobb, J. E., Lambert, M. H., Kurokawa, R., Rosenfeld, M. G., Willson, T. M., Glass, C. K., and Milburn, M. V. (1998) Ligand binding and co-activator assembly of the peroxisome proliferator-activated receptor-gamma. Nature 395, 137-143

10. Millard, C. J., Watson, P. J., Fairall, L., and Schwabe, J. W. (2013) An evolving understanding of nuclear receptor coregulator proteins. J Mol Endocrinol 51, T23-36

11. Hughes, T. S., Chalmers, M. J., Novick, S., Kuruvilla, D. S., Chang, M. R., Kamenecka, T. M., Rance, M., Johnson, B. A., Burris, T. P., Griffin, P. R., and Kojetin, D. J. (2012) Ligand and receptor dynamics contribute to the mechanism of graded PPAR $\gamma$ agonism. Structure 20, 139-150

12. Hughes, T. S., Giri, P. K., de Vera, I. M. S., Marciano, D. P., Kuruvilla, D. S., Shin, Y., Blayo, A.-L., Kamenecka, T. M., Burris, T. P., Griffin, P. R., and Kojetin, D. J. (2014) An 
bioRxiv preprint doi: https://doi.org/10.1101/351346; this version posted August 13,2018 . The copyright holder for this preprint (which was not certified by peer review) is the author/funder, who has granted bioRxiv a license to display the preprint in perpetuity. It is made available under aCC-BY 4.0 International license.

Structure-function analysis of 1-hydroxypioglitazone

alternate binding site for PPAR $\gamma$ ligands. Nat Commun $\mathbf{5}$

13. Ge, K., Guermah, M., Yuan, C. X., Ito, M., Wallberg, A. E., Spiegelman, B. M., and Roeder, R. G. (2002) Transcription coactivator TRAP220 is required for PPAR gamma 2stimulated adipogenesis. Nature 417, 563-567

14. Nagy, L., and Schwabe, J. W. R. (2004) Mechanism of the nuclear receptor molecular switch. Trends Biochem Sci 29, 317-324

15. Marciano, D. P., Kuruvilla, D. S., Boregowda, S. V., Asteian, A., Hughes, T. S., GarciaOrdonez, R., Corzo, C. A., Khan, T. M., Novick, S. J., Park, H., Kojetin, D. J., Phinney, D. G., Bruning, J. B., Kamenecka, T. M., and Griffin, P. R. (2015) Pharmacological repression of PPARgamma promotes osteogenesis. Nat Commun 6, 7443

16. Bruning, J. B., Chalmers, M. J., Prasad, S., Busby, S. A., Kamenecka, T. M., He, Y., Nettles, K. W., and Griffin, P. R. (2007) Partial agonists activate PPARgamma using a helix 12 independent mechanism. Structure 15, 1258-1271

17. Hughes, T. S., Shang, J., Brust, R., de Vera, I. M. S., Fuhrmann, J., Ruiz, C., Cameron, M. D., Kamenecka, T. M., and Kojetin, D. J. (2016) Probing the Complex Binding Modes of the PPAR $\gamma$ Partial Agonist 2-Chloro-N-(3-chloro-4-((5-chlorobenzo[d]thiazol-2yl)thio)phenyl)-4-(trifluoromethyl)benzenesulfonamide (T2384) to Orthosteric and Allosteric Sites with NMR Spectroscopy. Journal of Medicinal Chemistry 59, 1033510341

18. Choi, J. H., Banks, A. S., Estall, J. L., Kajimura, S., Bostrom, P., Laznik, D., Ruas, J. L., Chalmers, M. J., Kamenecka, T. M., Bluher, M., Griffin, P. R., and Spiegelman, B. M. (2010) Anti-diabetic drugs inhibit obesity-linked phosphorylation of PPARgamma by Cdk5. Nature 466, 451-456

19. Choi, J. H., Banks, A. S., Kamenecka, T. M., Busby, S. A., Chalmers, M. J., Kumar, N., Kuruvilla, D. S., Shin, Y., He, Y., Bruning, J. B., Marciano, D. P., Cameron, M. D., Laznik, D., Jurczak, M. J., Schurer, S. C., Vidovic, D., Shulman, G. I., Spiegelman, B. M., and Griffin, P. R. (2011) Antidiabetic actions of a non-agonist PPARgamma ligand blocking Cdk5-mediated phosphorylation. Nature 477, 477-481

20. Lee, M. A., Tan, L., Yang, H., Im, Y.-G., and Im, Y. J. (2017) Structures of PPAR $\gamma$ complexed with lobeglitazone and pioglitazone reveal key determinants for the recognition of antidiabetic drugs. Scientific Reports 7, 16837

21. Lehrke, M., and Lazar, M. A. (2005) The many faces of PPARgamma. Cell 123, 993-999

22. Alvarez-Sánchez, R., Montavon, F., Hartung, T., and Pähler, A. (2006) Thiazolidinedione Bioactivation: A Comparison of the Bioactivation Potentials of Troglitazone, Rosiglitazone, and Pioglitazone Using Stable Isotope-Labeled Analogues and Liquid Chromatography Tandem Mass Spectrometry. Chemical Research in Toxicology 19, 11061116

23. Jaakkola, T., Laitila, J., Neuvonen, P. J., and Backman, J. T. (2006) Pioglitazone is Metabolised by CYP2C8 and CYP3A4 in vitro: Potential for Interactions with CYP2C8 Inhibitors. Basic \& Clinical Pharmacology \& Toxicology 99, 44-51

24. Eckland, D. A., and Danhof, M. (2000) Clinical pharmacokinetics of pioglitazone. Exp Clin Endocrinol Diabetes 108, 234-242

25. Krieter, P. A., Colletti, A. E., Doss, G. A., and Miller, R. R. (1994) Disposition and metabolism of the hypoglycemic agent pioglitazone in rats. Drug Metabolism and Disposition 22, 625-630 
bioRxiv preprint doi: https://doi.org/10.1101/351346; this version posted August 13,2018 . The copyright holder for this preprint (which was not certified by peer review) is the author/funder, who has granted bioRxiv a license to display the preprint in perpetuity. It is made available under aCC-BY 4.0 International license.

\section{Structure-function analysis of 1-hydroxypioglitazone}

26. Tanis, S. P., Parker, T. T., Colca, J. R., Fisher, R. M., and Kletzein, R. F. (1996) Synthesis and Biological Activity of Metabolites of the Antidiabetic, Antihyperglycemic Agent Pioglitazone. Journal of Medicinal Chemistry 39, 5053-5063

27. Hughes, T. S., Chalmers, M. J., Novick, S., Kuruvilla, D. S., Chang, M. R., Kamenecka, T. M., Rance, M., Johnson, B. A., Burris, T. P., Griffin, P. R., and Kojetin, D. J. (2012) Ligand and receptor dynamics contribute to the mechanism of graded PPAR-gamma agonism. Structure 20, 139-150

28. Williamson, M. P. (2013) Using chemical shift perturbation to characterise ligand binding. Progress in Nuclear Magnetic Resonance Spectroscopy 73, 1-16

29. Edman, K., Hosseini, A., Bjursell, M. K., Aagaard, A., Wissler, L., Gunnarsson, A., Kaminski, T., Köhler, C., Bäckström, S., Jensen, T. J., Cavallin, A., Karlsson, U., Nilsson, E., Lecina, D., Takahashi, R., Grebner, C., Geschwindner, S., Lepistö, M., Hogner, A. C., and Guallar, V. (2015) Ligand Binding Mechanism in Steroid Receptors: From Conserved Plasticity to Differential Evolutionary Constraints. Structure 23, 2280-2290

30. Konermann, L., Pan, J., and Liu, Y. H. (2011) Hydrogen exchange mass spectrometry for studying protein structure and dynamics. Chem Soc Rev 40, 1224-1234

31. Kojetin, D. J., and Burris, T. P. (2013) Small molecule modulation of nuclear receptor conformational dynamics: implications for function and drug discovery. Mol Pharmacol 83, $1-8$

32. Schernthaner, G., Currie, C. J., and Schernthaner, G.-H. (2013) Do We Still Need Pioglitazone for the Treatment of Type 2 Diabetes? A risk-benefit critique in 2013. Diabetes Care 36, S155-S161

33. Raz, I. (2013) Guideline Approach to Therapy in Patients With Newly Diagnosed Type 2 Diabetes. Diabetes Care 36, S139-S144

34. Gao, W., Bohl, C. E., and Dalton, J. T. (2005) Chemistry and Structural Biology of Androgen Receptor. Chem Rev 105, 3352-3370

35. Pereira de Jésus-Tran, K., Côté, P.-L., Cantin, L., Blanchet, J., Labrie, F., and Breton, R. (2006) Comparison of crystal structures of human androgen receptor ligand-binding domain complexed with various agonists reveals molecular determinants responsible for binding affinity. Protein Sci 15, 987-999

36. Ostrowski, J., Kuhns, J. E., Lupisella, J. A., Manfredi, M. C., Beehler, B. C., Krystek, J. S. R., Bi, Y., Sun, C., Seethala, R., Golla, R., Sleph, P. G., Fura, A., An, Y., Kish, K. F., Sack, J. S., Mookhtiar, K. A., Grover, G. J., and Hamann, L. G. (2007) Pharmacological and XRay Structural Characterization of a Novel Selective Androgen Receptor Modulator: Potent Hyperanabolic Stimulation of Skeletal Muscle with Hypostimulation of Prostate in Rats. Endocrinology 148, 4-12

37. Mohler, M. L., Bohl, C. E., Jones, A., Coss, C. C., Narayanan, R., He, Y., Hwang, D. J., Dalton, J. T., and Miller, D. D. (2009) Nonsteroidal Selective Androgen Receptor Modulators (SARMs): Dissociating the Anabolic and Androgenic Activities of the Androgen Receptor for Therapeutic Benefit. Journal of Medicinal Chemistry 52, 35973617

38. Fabian, C., Tilzer, L., and Sternson, L. (1981) Comparative binding affinities of tamoxifen, 4-hydroxytamoxifen, and desmethyltamoxifen for estrogen receptors isolated from human breast carcinoma: Correlation with blood levels in patients with metastatic breast cancer. Biopharmaceutics \& Drug Disposition 2, 381-390 
39. Shiau, A. K., Barstad, D., Loria, P. M., Cheng, L., Kushner, P. J., Agard, D. A., and Greene, G. L. (1998) The structural basis of estrogen receptor/coactivator recognition and the antagonism of this interaction by tamoxifen. Cell 95, 927-937

40. Maximov, P. Y., Lee, T. M., and Jordan, V. C. (2013) The Discovery and Development of Selective Estrogen Receptor Modulators (SERMs) for Clinical Practice. Current Clinical Pharmacology 8, 135-155

41. Dai, S. Y., Chalmers, M. J., Bruning, J., Bramlett, K. S., Osborne, H. E., MontroseRafizadeh, C., Barr, R. J., Wang, Y., Wang, M., Burris, T. P., Dodge, J. A., and Griffin, P. R. (2008) Prediction of the tissue-specificity of selective estrogen receptor modulators by using a single biochemical method. Proc Natl Acad Sci U S A 105, 7171-7176

42. Rangwala, S. M., and Lazar, M. A. (2002) The dawn of the SPPARMs? Sci STKE 2002, pe9

43. Marciano, David P., Chang, Mi R., Corzo, Cesar A., Goswami, D., Lam, Vinh Q., Pascal, Bruce D., and Griffin, Patrick R. (2014) The Therapeutic Potential of Nuclear Receptor Modulators for Treatment of Metabolic Disorders: PPAR $\gamma$, RORs, and Rev-erbs. Cell Metabolism 19, 193-208

44. Snyder, P. W., Mecinović, J., Moustakas, D. T., Thomas, S. W., Harder, M., Mack, E. T., Lockett, M. R., Héroux, A., Sherman, W., and Whitesides, G. M. (2011) Mechanism of the hydrophobic effect in the biomolecular recognition of arylsulfonamides by carbonic anhydrase. Proc Natl Acad Sci U S A 108, 17889-17894

45. Pascual, G., Fong, A. L., Ogawa, S., Gamliel, A., Li, A. C., Perissi, V., Rose, D. W., Willson, T. M., Rosenfeld, M. G., and Glass, C. K. (2005) A SUMOylation-dependent pathway mediates transrepression of inflammatory response genes by PPAR-gamma. Nature 437, 759-763

46. Keller, S., Vargas, C., Zhao, H., Piszczek, G., Brautigam, C. A., and Schuck, P. (2012) High-Precision Isothermal Titration Calorimetry with Automated Peak Shape Analysis. Anal Chem 84, 5066-5073

47. Brautigam, C. A., Zhao, H., Vargas, C., Keller, S., and Schuck, P. (2016) Integration and global analysis of isothermal titration calorimetry data for studying macromolecular interactions. Nat Protoc 11, 882

48. Brautigam, C. A. (2015) Chapter Five - Calculations and Publication-Quality Illustrations for Analytical Ultracentrifugation Data. in Methods Enzymol (Cole, J. L. ed.), Academic Press. pp 109-133

49. Johnson, B. A. (2004) Using NMRView to visualize and analyze the NMR spectra of macromolecules. Methods Mol Biol 278, 313-352

50. Battye, T. G., Kontogiannis, L., Johnson, O., Powell, H. R., and Leslie, A. G. (2011) iMOSFLM: a new graphical interface for diffraction-image processing with MOSFLM. Acta Crystallogr D Biol Crystallogr 67, 271-281

51. Winn, M. D., Ballard, C. C., Cowtan, K. D., Dodson, E. J., Emsley, P., Evans, P. R., Keegan, R. M., Krissinel, E. B., Leslie, A. G., McCoy, A., McNicholas, S. J., Murshudov, G. N., Pannu, N. S., Potterton, E. A., Powell, H. R., Read, R. J., Vagin, A., and Wilson, K. S. (2011) Overview of the CCP4 suite and current developments. Acta Crystallogr D Biol Crystallogr 67, 235-242

52. McCoy, A. J., Grosse-Kunstleve, R. W., Adams, P. D., Winn, M. D., Storoni, L. C., and Read, R. J. (2007) Phaser crystallographic software. J Appl Crystallogr 40, 658-674 
53. Adams, P. D., Afonine, P. V., Bunkoczi, G., Chen, V. B., Echols, N., Headd, J. J., Hung, L. W., Jain, S., Kapral, G. J., Grosse Kunstleve, R. W., McCoy, A. J., Moriarty, N. W., Oeffner, R. D., Read, R. J., Richardson, D. C., Richardson, J. S., Terwilliger, T. C., and Zwart, P. H. (2011) The Phenix software for automated determination of macromolecular structures. Methods 55, 94-106

54. Nolte, R. T., Wisely, G.B., Westin, S., Cobb, J.E., Lambert, M.H., Kurokawa, R., Rosenfeld, M.G., Willson, T.M., Glass, C.K. and Milburn, M.V. (1988) Ligand binding and co-activator assembly of the peroxisome proliferator-activated receptor- $\gamma$. Nature 395, 137-143

55. Emsley, P., and Cowtan, K. (2004) Coot: model-building tools for molecular graphics. Acta Crystallogr D Biol Crystallogr 60, 2126-2132

56. Chalmers, M. J., Busby, S. A., Pascal, B. D., He, Y., Hendrickson, C. L., Marshall, A. G., and Griffin, P. R. (2006) Probing protein ligand interactions by automated hydrogen/deuterium exchange mass spectrometry. Anal Chem 78, 1005-1014

57. Pascal, B. D., Willis, S., Lauer, J. L., Landgraf, R. R., West, G. M., Marciano, D., Novick, S., Goswami, D., Chalmers, M. J., and Griffin, P. R. (2012) HDX workbench: software for the analysis of H/D exchange MS data. Journal of the American Society for Mass Spectrometry 23, 1512-1521

\section{FOOTNOTES}

This work was supported by National Institutes of Health (NIH) grants R01DK101871 (DJK), R01DK105825 (PRG), and F32DK108442 (RB); National Science Foundation (NSF) funding to the Summer Undergraduate Research Fellows (SURF) program at Scripps Research [Grant 1659594]; and the Academic Year Research Internship for Undergraduates (AYRIU) program at Scripps Research. 